\title{
Comparison of SHF and SSF Processes under Fed Batch Mode on Ethanol Production from Pretreated Vegetable Processing Residues
}

\author{
Madhanamohanan G. Mithra ${ }^{1}$, Moothandassery S. Sajeev ${ }^{1}$, Gouri Padmaja ${ }^{1 *}$ \\ ${ }^{1}$ Division of Crop Utilization, ICAR-Central Tuber Crops Research Institute, Thiruvananthapuram- 695 017, Kerala, \\ INDIA
}

*Corresponding Author: padmajabn@yahoo.com

Citation: Mithra, M. G., Sajeev, M. S. and Padmaja, G. (2019). Comparison of SHF and SSF Processes under Fed Batch Mode on Ethanol Production from Pretreated Vegetable Processing Residues. European Journal of Sustainable Development Research, 3(2), em0084. https://doi.org/10.20897/ ejosdr/3950

Published: March 3, 2019

\begin{abstract}
Vegetable wastes containing high starch in contrast to lignocellulosic biomass cause environmental threat due to non-judicious disposal and have not been exploited for bioethanol production. The ethanol production from steam or dilute sulphuric acid (DSA) pretreated residues was compared under fed-batch Separate Hydrolysis and Fermentation (F-SHF) or Simultaneous Saccharification and fermentation (F-SSF). The volumetric ethanol productivity, ethanol yields and ethanol contents $(\mathrm{g} / \mathrm{L})$ were higher from DSA than steam pretreatment in F-SHF, while latter two did not differ significantly between the pretreatments under F-SSF mode. High RS utilization was observed towards the last phase $(72-120 \mathrm{~h})$ in steam pretreatment under F-SSF. Fermented broth from F-SSF had higher levels of inhibitors such as phenolics, furfural and Hydroxymethyl furfural compared to F-SHF and also in the DSA pretreatment. A comparison of the ethanol production from the processes vis-à-vis enzyme and yeast feeding and pretreatment conditions, overall processing time etc. showed that F-SSF had higher requirement of enzymes and yeast than F-SHF. Possibility to curtail fermentation at $24 \mathrm{~h}$ under F-SHF mode due to very low ethanol production after 24 $\mathrm{h}$ equated the processing time under the two modes to $120 \mathrm{~h}$ and this made F-SHF the most advantageous process for the selected residues.
\end{abstract}

Keywords: pretreated vegetable residues, fed batch-SHF, fed batch-SSF, volumetric ethanol productivity

\section{INTRODUCTION}

The global research efforts on alternative biofuel sources gained momentum approximately two decades ago, mainly due to the critical imperatives such as rapidly depleting natural fuel sources pushing the world to energy insecurity, global warming from the burning of coal, oil or natural gas, emission of greenhouse gases (GHGs) from the transportation and industrial sectors affecting the ecosystem as a whole etc. (Sarkar et al., 2012; Sun and Cheng, 2002; Zhang and Shahbazi, 2011; Zhang et al., 2018). Owing to its ability to reduce GHG emission by $86 \%$, bioethanol is regarded as an economically and environmentally safe 'green fuel' of future (Farrel et al., 2006; Taherzadeh and Karimi, 2008). Extensive research has been done in the past two to three decades on ethanol production from lignocellulosic feedstock such as woody biomass, agricultural residues (rice straw, wheat straw, corn stover etc.) or dedicated grass (switch grass, Bermuda grass, Miscanthus etc.) and several reviews have appeared on these (Sarkar et al., 2012; Wyman, 1999; Yang and Wyman, 2008). Although renewability and cheap/abundant availability are positive attributes favouring lignocellulosic biomass (LCBs) as potential candidates for second generation $(2 \mathrm{G})$ ethanol production, their commercial exploitation is still challenged by several technological barriers such as high biomass recalcitrance necessitating rigorous pretreatment procedures, need for a complement 
of enzymes for high fermentable sugar yield, compositional variations affecting pretreatment and saccharification efficiency etc. (Himmel et al., 2007; Wyman., 1999). A number of pretreatment strategies including physical, chemical, biological or combined treatments have been reported for biomass residues such as corn stover, sugarcane bagasse, wheat/rice straw etc. (Alvira et al., 2010; Yang and Wyman, 2008). Nevertheless processing residues from industrial and food crops stand apart from the typical LCBs due to their compositional differences (especially having a high content of starch in them) enabling their grouping as lignocellulo-starch biomass (LCSB). The large volume of production coupled with the no-cost status and environmental hazards from the non-judicious disposal in open yards leading to spread of several contagious/vector-borne diseases necessitate the effective valorization of such wastes as bioethanol feedstock (Matsakas et al., 2014). Despite some research efforts on the potential of municipal waste and other household wastes as bioethanol raw materials (Li et al., 2007; Lissens et al., 2004), a large part still remains under-exploited. Vegetable processing wastes are generated from domestic and food service/catering units, retail hotel outlets etc. and a major challenge concerning their utilization is the heterogeneity due to the type of vegetables processed, region-wise differences in the food habits, seasonal changes deciding the pattern of vegetable use etc. (Lin et al., 2013; Luque and Clark, 2013). Tang et al. (2008) reported the suitability of vegetable wastes as feedstock for ethanol production due to their high starch content, besides cellulose and hemicellulose and also because of their non-competitiveness with food sources. The feasibility of such wastes for bioethanol production depends on the type of pretreatment needed to deconstruct the lignocellulosic backbone, enzymatic saccharification protocols to realise the highest fermentable sugar yield from them as well as the fermentation strategies enabling maximum ethanol conversion from sugars (Himmel et al., 2007; Singh et al., 2012; Wyman., 1999).

Apart from the pretreatment associated cost, one of the major factors contributing to the economics of $2 \mathrm{G}$ ethanol is the recovery cost and bioethanol production could be made cost-effective only when ethanol levels are $>40 \mathrm{~g} / \mathrm{L}$, which in turn requires a fermentable sugar yield of $>80 \mathrm{~g} / \mathrm{L}$ in the hydrolysate (Zacchi and Axelsson., 1989). Two approaches to achieve high sugar yield in hydrolysates include high initial substrate loading (Hodge et al., 2008; Zhang et al., 2009) and fed-batch saccharification where pulsed addition of substrate enables mitigation of enzyme inhibition by end products as well as ensures proper mixing and heat transfer in biomass slurries (Gupta et al., 2012; Rudolf et al., 2005). The commonly adopted methods for ethanol production are separate hydrolysis and fermentation (SHF) and simultaneous saccharification and fermentation (SSF) and the advantages and disadvantages of these for a large number of LCBs have been documented (Öhgren et al., 2007; Saha et al., 2013; Taherzadeh and Karimi, 2008).

The potential of processing residues such as peels of root crops and vegetables as bioethanol feedstock was investigated by Mithra and Padmaja (2016 a, 2017 a). Due to the high content of starch, these LCSBs required different pretreatment as well as saccharification approaches and whole slurry saccharification also necessitated appropriate removal of fermentation/saccharification inhibitors through the use of detoxification chemicals (Mithra and Padmaja, 2016 b). Furthermore while the typical LCBs required only a complement of cellulases and xylanases for saccharification (Bussamra et al., 2015; Zhang et al., 2013), LCSBs also needed starch hydrolysing enzyme as an additional component of the cocktail (Mithra and Padmaja, 2017 b; Mithra et al., 2017). The present study aimed at a comparison of the ethanol production from peels of certain routinely used vegetables in India and also from the mixed vegetable waste (comprising peels, seeds, unused/damaged part of vegetables etc.) collected from domestic sources and restaurant outlets. The vegetables covered under the study included ash gourd (Benincasa hispida), pumpkin (Cucurbita moschata) and vegetable (cooking) banana (Musa spp. ABB). Ash gourd is cultivated as a vegetable in India, China, Japan and Australia (Anon., 1962) and approximately 500-700 kg peels are generated per day during commercial processing for sweet manufacture in India (Sreenivas et al., 2011), besides considerable quantities from domestic/catering sources. Pumpkin is cultivated extensively in several countries such as Mexico, India, Argentina, Brazil, America and China (Zhou et al., 2007). Approximately 15-30\% goes as waste peels during processing for edible or therapeutic applications. Banana is another important food crop of the tropical and sub-tropical regions with India topping the list in production (FAOSTAT, 2016). Among the edible varieties approximately $32 \%$ of the bananas fall under the category of cooking bananas and their processing at domestic or industrial level generates huge waste in the form of peels, which are also rich in starch (Mithra and Padmaja., 2017 a). Previous studies standardized the optimum pretreatment and saccharification conditions for these biomass residues (Mithra and Padmaja, 2017b; Mithra et al., 2017) and it was subsequently found that high fermentable sugar yield could be realised through fed-batch substrate loading (Mithra et al., 2018). The objective of the present study was to compare the ethanol yields from these residues by the two fermentation modes such as SHF and SSF adopting a high cumulative substrate loading by fed-batch approach and minimising the effects of inhibitors through the use of detoxification chemicals such as surfactants (Tween 20 and polyethylene glycol 4000) and sodium borohydride. 


\section{MATERIALS AND METHODS}

\section{Raw Materials}

Peels from vegetable crops such as ash gourd (AG), pumpkin (PK) and vegetable banana (VB) were collected by physically peeling them. These were washed in running water to free from adhering soil and dried in sunlight for $36-48 \mathrm{~h}$. These were powdered using a hammer mill to particles of $c a .2-3 \mathrm{~mm}$ size and the unscreened powder was utilized for the studies. Mixed vegetable wastes (MVW, comprising the non-edible parts such as peels, seeds and pulp part covering them and damaged parts of common vegetables), were collected from local restaurants and households and was dried as such in the sun without further washing. Previous studies on the composition of dry peels and MVW showed that they contained cellulose (13-19\%), hemicellulose (13-20\%), starch (27-32\%) and lignin (4-8\%) other than reducing and non-reducing sugars and ash (see Table 1) (Mithra and Padmaja., 2016 a; 2017 a).

\section{Enzymes and Chemicals}

The hydrolytic enzymes utilized for the study included Ecozyme RT80 (cellulolytic enzyme complex), Ecozyme XY50 (Xylanase) and Stargen ${ }^{\mathrm{TM}} 002$ (granular starch-hydrolysing enzyme) and the former two enzymes were provided by M/s Ecostar Ltd., Chennai, India while Stargen was gifted by M/s Genencor International Inc., USA (presently Genencor-Danisco, USA). The commercial enzyme preparation, Ecozyme RT80 was reported to contain 22 FPU (Filter Paper Units) of cellulase activity for each millilitre along with 328 units of $\beta$-glucosidase activity per millilitre and 126 units of $\alpha$-amylase activity per millilitre (Mithra et al., 2017). The cellulase activity of Ecozyme RT80 was quantified by the method standardized by NREL, USA (Ghose, 1987). One filter paper unit (FPU) of activity is defined as the amount of enzyme which releases 2-mg reducing sugar from a 50-mg filter paper (Whatman no. 1) in $1 \mathrm{~h}$. Ecozyme RT80 was also tested for the presence of co-activities such as $\beta$-glucosidase and $\alpha$-amylase. $\beta$-Glucosidase activity was assayed using cellobiose as substrate as per the method of Tomaz and Roche (2002). The assay system had $0.05 \mathrm{M}$ cellobiose solution $(0.4 \mathrm{ml})$ in $0.05 \mathrm{M}$ citrate buffer $(\mathrm{pH} 4.8)$ and $0.1 \mathrm{ml}$ of properly diluted enzyme and was incubated at $50{ }^{\circ} \mathrm{C}$ for $30 \mathrm{~min}$ after which glucose was quantified using arsenomolybdate reagent (Nelson, 1944). $\beta$-Glucosidase activity is expressed as the amount of glucose (mg) released from one gram cellobiose by one milliliter of enzyme in one hour and is equivalent to 15.19 International units (I.U). The $\alpha$-amylase activity of Ecozyme RT80 was determined as per the method of Divya Nair et al. (2011) using $1 \%$ cassava (Manihot esculenta Crantz) starch as substrate. The assay system had $1.0 \mathrm{ml}$ of $1 \%$ gelatinized cassava starch, $3.5 \mathrm{ml}$ acetate buffer $(0.1 \mathrm{M} ; \mathrm{pH} 5.0)$ and $0.5 \mathrm{ml}$ enzyme and the system was incubated at $50{ }^{\circ} \mathrm{C}$ for one hour, and glucose was quantified using the arsenomolybdate reagent. The $\alpha$-amylase activity unit is expressed as the amount of glucose $(\mathrm{mg})$ released in $1 \mathrm{~h}$ from one gram starch by one milliliter of enzyme and is equivalent to 5.83 International units (I.U). One I.U is the amount of enzyme that could produce 2 micromoles of glucose per minute from the respective substrates. Stargen ${ }^{\mathrm{TM}} 002$ contained Aspergillus kawachi $\alpha$-amylase (E.C. 3.2.1.1) expressed in Trichoderma reesei and a glucoamylase (E.C. 3.2.1.3) from Trichoderma reesei that work together to hydrolyse granular starch substrate to glucose. It has an activity of 570 glucoamylase units (GAU) per gram, and one GAU is the measure of enzyme that will release one gram of reducing sugars (as glucose) per hour from starch under the conditions of assay (Anon., 2009). Ecozyme RT80, Stargen and Ecozyme XY50 contained 78.8, 216.0 and $5.25 \mathrm{mg}$ crude protein per millilitre respectively (Mithra et al., 2017).

\section{Pretreatment}

Two best pretreatments based on the efficiency of deconstruction were chosen which included steam pretreatment and DSA pretreatment. Ten grams of dry biomass powders were moistened with de-ionized water to raise the moisture content to $40 \%$ and exposed to room temperature $\left(30 \pm 1^{\circ} \mathrm{C}\right)$ for $10 \mathrm{~min}$ in order to distribute water uniformly within the samples.

The moist samples were then spread on a wet (drained) muslin cloth and placed on the steamer tray (with pores) of a vegetable steamer (M/s TTK Prestige India Ltd., India) and subjected to steam treatment at $100{ }^{\circ} \mathrm{C}$ under atmospheric pressure for $45 \mathrm{~min}$ (Mithra and Padmaja, 2016 a). In DSA pretreatment, the dry biomass $(10 \mathrm{~g}$ initially) was mixed with $100 \mathrm{ml} 0.1 \mathrm{M} \mathrm{H}_{2} \mathrm{SO}_{4}$ and exposed to heat in a pressure cooker (M/s TTK Prestige India Ltd., India) for $60 \mathrm{~min}$ at $121{ }^{\circ} \mathrm{C}$ and pressure of $0.102 \mathrm{MPa}$ (time noted after pressure build-up) (Mithra and Padmaja, 2016 a). Subsequent batches of substrates needed for the fed batch experiments were also pretreated similarly before addition.

\section{Fed-Batch Separate Hydrolysis and Fermentation (F-SHF)}

The fed batch experiment was started with steam or DSA pretreated biomass (equivalent to $10 \mathrm{~g}$ dry weight) prepared as above. The slurry was made up to $90 \mathrm{ml}$ in $250 \mathrm{ml}$ Erlenmeyer flasks and after pH adjustment to 5.0 the samples were equilibrated in a thermostatic water bath at $50{ }^{\circ} \mathrm{C}$. Both the slurries were treated with sodium 
azide $(0.25 \% \mathrm{w} / \mathrm{v})$ as antimicrobial agent and detoxification chemical mix containing Tween $20(0.25 \% \mathrm{v} / \mathrm{v})$, Polyethylene glycol 4000 (PEG, $0.25 \% \mathrm{w} / \mathrm{v}$ ) and sodium borohydride $\left(\mathrm{NaBH}_{4} ; 0.151 \% \mathrm{w} / \mathrm{v}\right.$ ) and kept at room temperature $\left(30 \pm 1{ }^{\circ} \mathrm{C}\right)$ for $30 \mathrm{~min}$ to provide adequate time for removal of phenolic/other inhibitors from the pretreated slurry. The levels of the detoxifying chemicals were standardized through an earlier study and selected based on their capacity to channel out maximum quantity of phenolic compounds (Mithra and Padmaja, 2016 b). The treated slurries after $\mathrm{pH}$ adjustment to 5.0 and volume increment to $100 \mathrm{ml}$ were equilibrated in a shaking water bath (M/s JULABO Industries, Germany) for $10 \mathrm{~min}$ at $50^{\circ} \mathrm{C}$ and shaking speed of $100 \mathrm{rpm}$.

An enzyme cocktail containing Ecozyme RT80 (16 FPU/g cellulose), Ecozyme XY50 (3 mg protein/g hemicellulose) and Stargen ( $0.25 \mathrm{ml}$ equivalent to $54 \mathrm{mg}$ protein $/ 10 \mathrm{~g}$ biomass) was added to steam pretreated slurries. Due to the high hydrolysis of starch in DSA pretreated slurries (85-94\%), the dosage level of Stargen was reduced to half $(0.125 \mathrm{ml}$ equivalent to $27 \mathrm{mg}$ protein $/ 10 \mathrm{~g}$ biomass) while maintaining the same levels of Ecozyme RT 80 and Ecozyme XY50 as optimized earlier (Mithra et al., 2017). It was reported earlier that steam pretreatment removed $10 \%$ cellulose, $18 \%$ hemicellulose and 36\% starch from the selected residues, while DSA removed 3.617.4\% cellulose, 42-48\% hemicellulose and 85-95\% starch (Mithra and Padmaja, 2016 a, 2017 a) and hence the dose of Stargen was halved. Both the slurries were incubated at $50{ }^{\circ} \mathrm{C}$ for $24 \mathrm{~h}$ in a shaking water bath at a speed of $100 \mathrm{rpm}$.

Three graded levels of pretreated slurries such as $5 \mathrm{~g} / 20 \mathrm{ml}, 5 \mathrm{~g} / 20 \mathrm{ml}$ and $2.5 \mathrm{~g} / 10 \mathrm{ml}$ were added subsequently at $24 \mathrm{~h}, 48 \mathrm{~h}$, and $72 \mathrm{~h}$ of incubation without any additional enzyme loading but with exposure to the detoxification chemicals at proportionate levels for the same time mentioned earlier. Incubation was continued up to $96 \mathrm{~h}$ after which the slurries were centrifuged at $3000 \mathrm{rpm}$ for $15 \mathrm{~min}$ and the clear supernatant was used for the fermentation experiment.

The reducing sugar content in the hydrolysates was monitored every $24 \mathrm{~h}$ using arsenomolybdate reagent (Nelson, 1944) and expressed as $\mathrm{g} / \mathrm{L}$ (equivalent to that released from $150 \mathrm{~g}$ biomass as $15 \% \mathrm{w} / \mathrm{v}$ solid loading was adopted). All the experiments were run in triplicates and enzyme blanks as well as substrate blanks were kept to avoid the interference from sugars and original biomass respectively.

\section{Hydrolysis Yield (HY)}

The Hydrolysis yield (\%) from F-SHF was computed from the RS values in the $96 \mathrm{~h}$ hydrolysates (which include the sugars formed after pretreatment as well) as percentage of the potential sugar content in each biomass using the formula:

$$
\text { Hydrolysis yield }(\mathrm{HY} \%)=\frac{\text { Reducing sugar content }(g / L) \times 100}{[(\mathrm{C}+\mathrm{S}) \times 1.11+\mathrm{HC} \times 1.14+\text { total sugars }] \times \mathrm{A}}
$$

where C: cellulose, HC: hemicellulose and S: starch expressed as $\mathrm{g} / 100 \mathrm{~g}$ original dry biomass and $\mathrm{A}$ is 1.5 for 150 $\mathrm{g}$ biomass per litre. 1.11 is the conversion factor for cellulose or starch to sugars, while 1.14 is the conversion factor for hemicellulose to sugars (Thomsen et al., 2014).

\section{Fermentation Setup}

The fermentation experiments were conducted in $250 \mathrm{ml}$ Erlenmeyer flasks using $150 \mathrm{ml}$ clear hydrolysate from saccharification and the $\mathrm{pH}$ was adjusted to 4.5 prior to equilibration in a thermostatic water bath at $37^{\circ} \mathrm{C}$ for 10 min at a shaking speed of $100 \mathrm{rpm}$.

\section{Activation of Yeast}

Dry Baker's yeast (Saccharomyces cerevisiae) was activated by allowing it to proliferate on $10 \%$ sucrose solution $(20 \% \mathrm{w} / \mathrm{v})$ at $37^{\circ} \mathrm{C}$ for $1 \mathrm{~h}$ and from this $7.5 \mathrm{ml}$ yeast suspension was used for each $150 \mathrm{ml}$ hydrolysate.

\section{Nutrient Solution}

The stock nutrient solution contained ammonium sulphate $(1.0 \mathrm{~g})$, copper sulphate $(0.004 \mathrm{~g})$, magnesium sulphate $(0.35 \mathrm{~g})$ and calcium chloride $(0.055 \mathrm{~g})$ in one litre distilled water. An aliquot of $0.25 \mathrm{ml}$ from this stock mix was added to each $150 \mathrm{ml}$ hydrolysate.

\section{Fermentation to Ethanol}

Activated yeast $(7.5 \mathrm{ml})$ along with $0.25 \mathrm{ml}$ nutrient solution was added to $150 \mathrm{ml}$ hydrolysate. The flasks after covering with aluminium foil were fermented for $72 \mathrm{~h}$. Destructive sampling was done at $24 \mathrm{~h}, 48 \mathrm{~h}$ and $72 \mathrm{~h}$ in order to prevent the entry of air into the fermentation system during sampling. The fermented broth (after $72 \mathrm{~h}$ ) was centrifuged at $3000 \mathrm{rpm}$ for $15 \mathrm{~min}$ and the cell free supernatant was utilized for the determination of RS and ethanol content. Ethanol content was measured by the spectrophotometric method of Caputi et al. (1968) utilizing potassium dichromate reagent. The broth after $72 \mathrm{~h}$ fermentation was also distilled using a rotary evaporator (Ms BUCHI India Pvt. Ltd., India) at $70{ }^{\circ} \mathrm{C}$ to measure the recovery of ethanol. The distilled ethanol was mixed with 
anhydrous sodium sulphate $(5 \mathrm{~g} / 100 \mathrm{ml}$ distillate) to eliminate the last traces of water and the volume was measured.

\section{Fed-Batch Simultaneous Saccharification and Fermentation (F-SSF)}

A feeding strategy proportionate with the quantity of substrate loading, involving enzymes, detoxification chemicals, yeast and nutrient solution was adopted in F-SSF, while in F-SHF only detoxification chemicals were fed along with substrate at three time points $(24 \mathrm{~h}, 48 \mathrm{~h}$ and $72 \mathrm{~h}$ ).

Ten grams of dry biomass were moistened to $40 \%$ moisture content and exposed to steam for 45 min as reported (Mithra and Padmaja, 2016 a). The steam pretreated material was reconstituted using $90 \mathrm{ml}$ water and after $\mathrm{pH}$ adjustment to 5.0 , the samples were equilibrated in a thermostatic water bath at $37^{\circ} \mathrm{C}$. Sodium azide $(0.25 \% \mathrm{w} / \mathrm{v})$ and detoxification mix containing Tween $20(0.25 \% \mathrm{v} / \mathrm{v})$, PEG $(0.25 \% \mathrm{w} / \mathrm{v})$ and $\mathrm{NaBH}_{4}(0.151 \%$ $\mathrm{w} / \mathrm{v})$ were added to the slurry and kept for $30 \mathrm{~min}$ at room temperature for detoxification reaction. The triple enzyme cocktail containing Ecozyme RT80 (16 FPU/g cellulose), Ecozyme XY50 (3.0 mg protein/g hemicellulose) and Stargen ( $0.25 \mathrm{ml}$ equivalent to $54 \mathrm{mg}$ protein $/ 10 \mathrm{~g}$ biomass $)$ was added to each system. Activated yeast suspension $(10 \mathrm{ml})$ prepared as indicated under F-SHF along with nutrient solution $(0.20 \mathrm{ml})$ were added and after closing with aluminium foil, the flasks were incubated for $24 \mathrm{~h}$ at a shaking speed of $100 \mathrm{rpm}$.

Two more batches of the steam pretreated biomass (each $50 \mathrm{ml}$ containing $10 \mathrm{~g}$ dry weight + half the quantity of detoxification mix) were prepared and after adjusting the $\mathrm{pH}$ to 5.0 and addition of half the quantity of detoxification chemicals, the slurries were exposed to room temperature for $30 \mathrm{~min}$. Immediately after $24 \mathrm{~h}$ incubation and sampling, the first batch of $50 \mathrm{ml} \mathrm{pH}$ adjusted slurry along with $2.0 \mathrm{ml}$ yeast suspension was added, along with nutrient solution $(0.05 \mathrm{ml}$ ) and one-fourth the dose of enzymes (4 FPU Ecozyme RT80/g cellulose, $0.75 \mathrm{mg}$ protein of Ecozyme XY50/g hemicellulose and $0.06 \mathrm{ml}$ Stargen $/ 10 \mathrm{~g}$ biomass) an incubation was continued up to $48 \mathrm{~h}$.

The second batch of $\mathrm{pH}$ adjusted $50 \mathrm{ml}$ whole slurry (containing the next $10 \mathrm{~g}$ dry weight + detoxification chemicals), along with $2.0 \mathrm{ml}$ yeast suspension, nutrient solution $(0.05 \mathrm{ml})$ and one-fourth the dose of enzymes as described earlier were added at $48 \mathrm{~h}$. The cumulative biomass addition was $30 \mathrm{~g}$ in $200 \mathrm{ml}(15 \% \mathrm{w} / \mathrm{v})$ although at any point of sampling the weight may not be equivalent to $15 \% \mathrm{w} / \mathrm{v}$ as it was continuously hydrolysed by the enzymes. Incubation was continued up to $120 \mathrm{~h}$, with sampling for quantification of ethanol and RS at every $24 \mathrm{~h}$.

The same study was repeated for the DSA pretreated biomass (prepared as in F-SHF using $10 \mathrm{~g}$ dry biomass in $0.1 \mathrm{M} \mathrm{H}_{2} \mathrm{SO}_{4}$ ), except that the enzyme cocktail for first enzyme feeding had full dose of Ecozyme RT80 and Ecozyme XY50 along with half dose of Stargen $(0.125 \mathrm{ml} / 10 \mathrm{~g}$ biomass). The dosages for the second and third level of application of $10 \mathrm{~g}$ biomass in $100 \mathrm{ml}$ slurry volume at each loading were modified accordingly (4 FPU Ecozyme RT80/g cellulose, $0.75 \mathrm{mg}$ protein of Ecozyme XY50/g hemicellulose and $0.03 \mathrm{ml}$ Stargen/10 g biomass for each loading). Residual reducing sugars and ethanol were quantified after $120 \mathrm{~h}$ fermentation for both steam and DSA pretreated sets as described before.

The broth after $120 \mathrm{~h}$ fermentation was distilled using rotary evaporator and volume quantified as in the FSHF experiments described earlier.

\section{Calculation for Ethanol Yield Related Parameters}

The reducing sugar (RS) consumption in F-SHF was worked out as the difference between the initial RS (g/L) available for fermentation in $96 \mathrm{~h}$ hydrolysates and the RS $(\mathrm{g} / \mathrm{L})$ remaining in the fermented broth after $72 \mathrm{~h}$ fermentation. The other parameters related to ethanol fermentation were computed based on the earlier reports (Barcelos et al., 2011; Pereira et al., 2015; Yadav et al., 2011; Pooja et al., 2018) as given under:

$$
\begin{gathered}
\text { Ethanol yield }\left(\mathrm{Y}_{\mathrm{E}}\right)=\frac{\text { Ethanol concentration }(\mathrm{g} / \mathrm{L}) \text { in fermented broth }(\mathrm{Ef}) \mathrm{x} 1}{\text { Sugar consumed }(\mathrm{g} / \mathrm{L})} \\
\text { Fermentation Efficiency }(\%)=\frac{\text { Ethanol yield }\left(Y_{E}\right) \times 100}{\text { Theoretical ethanol yield }}
\end{gathered}
$$

Theoretical ethanol yield is $0.511 \mathrm{~g} / \mathrm{g}$ glucose consumed (Qin, 2010)

$$
\begin{gathered}
\text { Volumetric Ethanol productivity }(\mathrm{g} / \mathrm{L} . \mathrm{h})=\frac{\text { Ethanol concentration }(\mathrm{g} / \mathrm{L}) \text { in fermented broth }(\mathrm{Ef})}{\text { Fermentation time }(\mathrm{h})} \\
\text { Yield of Ethanol }(\mathrm{g} / \mathrm{kg}) \text { from dry biomass }=\frac{\mathrm{Ef} \times 1000}{\mathrm{~W} 1}
\end{gathered}
$$

where W1 is the weight of dry biomass in one litre slurry, which is $150 \mathrm{~g}$ for the fed-batch studies, 


$$
\text { Ethanol yield }(\mathrm{ml}) \text { from one kg biomass }=\frac{\mathrm{Ef} \times 1000}{\mathrm{~W} 1 \times 0.82}
$$

where 0.82 is the specific gravity of ethanol.

In order to compute sugar consumption in F-SSF, the initial available total sugars were computed from the potential sugar yielding carbohydrate content as:

Initial sugars $(\mathrm{g} / \mathrm{L})$ available for fermentation $(\mathrm{A})=$ Total potential sugars $(\mathrm{g} / 150 \mathrm{~g})$ in each biomass which was calculated as:

$$
((\mathrm{C}+\mathrm{S}) \times 1.11+\mathrm{HC} \times 1.14+\text { Total sugars }) \text { in } 100 \text { g dry biomass } \times 1.5
$$

where 1.5 is the factor to convert to $150 \mathrm{~g}$ biomass.

The unutilized sugars in the residue left after saccharification and fermentation were quantified by determining the total sugars by extracting them with $80 \%$ ethanol, converting the non-reducing sugars to reducing using acid hydrolysis and then estimating the RS using arsenomolybdate reagent (Nelson, 1944) and the total carbohydrate by using anthrone reagent (Hedge and Hofreiter, 1962). The quantity of biomass remaining after fermentation(120 SSF) was quantified and based on this, the sugars in the residue from $150 \mathrm{~g}$ biomass was worked out.

Unutilized sugars $(\mathrm{g} / \mathrm{L})(\mathrm{B})=($ Total sugars in fermented residue from $150 \mathrm{~g}$ biomass + total sugars $(\mathrm{g} / \mathrm{L})$ remaining in the fermented broth after $120 \mathrm{~h}$ )

$$
\text { Sugar consumption }\left(\frac{\mathrm{g}}{\mathrm{L}}\right) \text { during } \operatorname{SSF}(\mathrm{C})=\mathrm{A}-\mathrm{B}
$$

\section{HPLC Characterization of Monosaccharides and Furan Aldehydes}

Sugar profile was characterized in the $96 \mathrm{~h}$ hydrolysates from steam and DSA pretreated residues as well as after $72 \mathrm{~h}$ fermentation in F-SHF by HPLC. In F-SSF, the fermented broth after $120 \mathrm{~h}$ was used for characterization of monosaccharides. The clear supernatants obtained by the centrifugation of samples (single pooled sample from three replicates) at $3000 \mathrm{rpm}$ for $10 \mathrm{~min}$ were stored at $-4^{\circ} \mathrm{C}$ until use. At the time of assay, the filtrates were again passed through $0.2 \mu \mathrm{m}$ sterile filters (Millipore) and used for the HPLC characterization of sugars. Analysis of monomeric sugars was performed on an isocratic mode using HPLC (M/s Shimadzu, Kyoto, Japan) having a computer software based integration system. The conditions were: Column: SUPELCOSIL LC$\mathrm{NH}_{2}(250 \times 4.6 \mathrm{~mm})$, mobile phase: acetonitrile:water (75:25), flow rate: $1.0 \mathrm{ml} / \mathrm{min}$, column temperature: ambient $\left(30 \pm 1{ }^{\circ} \mathrm{C}\right)$, Detector: RID-10 A, injection volume: $20 \mu \mathrm{l}$ and run time: $30 \mathrm{~min}$.

Furfural and 5-hydroxymethyl furfural (HMF) were quantified in the same samples as above using HPLC with Zorbax-SB-C18 reverse phase column and Photodiode array (PDA-960) UV detector for HMF and Aminex-HPX$87 \mathrm{H}$ column $(250 \times 4.6 \mathrm{~mm}$ ) along with a Guard column (Aminex- HPX-87 H) and SPD-M20 A PDA UV detector for furfural. Other conditions were: mobile phase: Ultrapure water and $0.25 \mathrm{mM} \mathrm{H}_{2} \mathrm{SO}_{4}(4: 1)$, injection volume: 20 $\mu$ l, flow rate: $0.6 \mathrm{ml} / \mathrm{min}$ and total run time $40 \mathrm{~min}$ (furfural) and $55 \mathrm{~min}$ (HMF).

Peaks were identified and quantified by comparing with the retention times of authentic standards (glucose, xylose, arabinose, galactose, mannose, furfural and HMF), procured from M/s SIGMA, St. Louis, USA.

\section{Total Soluble Phenolics Content}

Total soluble phenolics (TSPs) content in the hydrolysates from vegetable residues after saccharification (96 $\mathrm{h}$ for SHF experiment) as well as after fermentation (both SHF (after $72 \mathrm{~h}$ ) and SSF (after $120 \mathrm{~h}$ )) were determined using Folin-Ciocalteu reagent (Singleton and Rossi, 1965) and expressed as gallic acid equivalents (g/L). Any interference from the detoxification agents (Tween 20, PEG4000 and sodium borohydride) was nullified in the assay by keeping a blank containing the same concentration of detoxification chemicals as in the test samples.

\section{Statistical Analysis}

The data from three replicates were analysed using the statistical package, SAS 9.3 to calculate the least significant difference (LSD) for pair-wise comparison of mean values (SAS, 2010).

\section{RESULTS AND DISCUSSION}

\section{Reducing Sugar Changes and Fermentative Performance during F-SHF and F-SSF}

The initial RS available for fermentation after the $96 \mathrm{~h}$ saccharification of vegetable peel and MVW hydrolysates as well as the total Hydrolysis Yield (HY) are presented in Table 2. It could be seen that in the case of both steam and DSA pretreatments, VB and PK peel hydrolysates had the highest RS content. This was because of the very high sugar yielding carbohydrate (cellulose +hemicellulose+starch) content in these residues compared to the other two (see Table 1). 
European Journal of Sustainable Development Research, 3(2), em0084

Table 1. Compositional profile* of selected vegetable processing residues (expressed as $\mathrm{g} / 100 \mathrm{~g}$ dry

basis)

\begin{tabular}{lcccccc}
\hline Biomass & Cellulose & Hemicellulose & Starch & Lignin & Total Sugars & Reducing Sugars \\
\hline AG peel & $18.67 \pm 0.77$ & $18.30 \pm 0.59$ & $19.91 \pm 0.39$ & $10.70 \pm 0.34$ & $6.30 \pm 0.05$ & $5.19 \pm 0.02$ \\
\hline PK peel & $21.05 \pm 0.79$ & $17.74 \pm 0.47$ & $24.61 \pm 0.00$ & $10.66 \pm 0.84$ & $8.73 \pm 0.06$ & $6.50 \pm 0.00$ \\
\hline VB peel & $22.40 \pm 0.64$ & $15.19 \pm 0.56$ & $36.56 \pm 0.00$ & $10.55 \pm 0.33$ & $2.77 \pm 0.01$ & $1.71 \pm 0.00$ \\
\hline MVW & $11.71 \pm 0.36$ & $11.97 \pm 0.04$ & $28.10 \pm 0.46$ & $7.55 \pm 0.38$ & $10.45 \pm 0.08$ & $7.50 \pm 0.07$ \\
\hline * Mean + SD from three replicates, AG: ash
\end{tabular}

* Mean \pm SD from three replicates, AG: ash gourd, PK: pumpkin, VB: vegetable banana, MVW: mixed vegetable waste, Data compiled

from Mithra and Padmaja (2016a, 2017a)

Table 2. Pattern of sugar consumption and ethanol yield during the course of fermentation (72 h) in Steam/DSA pretreated and saccharified hydrolysates from vegetable processing residues under SHF

\begin{tabular}{|c|c|c|c|c|c|c|c|c|c|c|c|c|c|c|}
\hline \multirow[t]{2}{*}{ Biomass } & \multirow{2}{*}{$\begin{array}{l}\text { Initial } \\
\text { sugars } \\
(\mathrm{g} / \mathrm{L})^{*}\end{array}$} & \multirow{2}{*}{$\begin{array}{l}\text { HY } \\
(\%)^{* *}\end{array}$} & \multicolumn{3}{|c|}{$\begin{array}{c}\text { Reducing sugar } \\
\text { consumption } \\
\text { during fermentation }(\mathrm{g} / \mathrm{L})\end{array}$} & \multicolumn{3}{|c|}{$\begin{array}{l}\text { Volumetric ethanol } \\
\text { productivity (g/L.h) }\end{array}$} & \multicolumn{3}{|c|}{$\begin{array}{l}\text { Ethanol yield } \\
\qquad\left(\mathrm{Y}_{\mathrm{E}}\right)^{* * *}\end{array}$} & \multicolumn{3}{|c|}{$\begin{array}{c}\text { Ethanol content } \\
(\mathrm{g} / \mathrm{L})\end{array}$} \\
\hline & & & $24 \mathrm{~h}$ & $48 \mathrm{~h}$ & $72 \mathrm{~h}$ & $24 \mathrm{~h}$ & $48 \mathrm{~h}$ & $72 \mathrm{~h}$ & $24 \mathrm{~h}$ & $48 \mathrm{~h}$ & & & $48 \mathrm{~h}$ & \\
\hline \multicolumn{15}{|c|}{ Steam pretreatment (ST) } \\
\hline AG peel & & $85.25^{\mathrm{c}}$ & & & 60 & $1.14^{\mathrm{d}}$ & & & & & & & $7.99 \mathrm{e}$ & \\
\hline & $4 \mathrm{~b}$ & & & & $80^{c}$ & $3 c$ & & & & & & $.63^{c}$ & $31.24^{c}$ & $6^{c}$ \\
\hline & & & & & $54^{\mathrm{b}}$ & $1.32^{\mathrm{c}}$ & & & $0.374^{b}$ & & $80^{\mathrm{b}}$ & $31.58^{\mathrm{c}}$ & $32.21^{\mathrm{c}}$ & $32.54^{c}$ \\
\hline MVW & $93.29 \mathrm{~d}$ & $91.07^{a}$ & $5.85^{\mathrm{e}}$ & $76.26^{\mathrm{d}}$ & $76.79^{\mathrm{d}}$ & $1.19^{\mathrm{d}}$ & & & $0.376^{\mathrm{b}}$ & & $0.382^{\mathrm{b}}$ & $28.50^{\mathrm{d}}$ & $29.06^{\mathrm{d}}$ & $29.36^{\mathrm{d}}$ \\
\hline \multicolumn{15}{|c|}{ DSA pretreatment (DSA) } \\
\hline $\mathrm{AG}$ peel & $83.88^{\mathrm{f}}$ & $79.90^{\mathrm{e}}$ & & & $72.84 \mathrm{e}$ & $1.40^{\mathrm{b}}$ & & & & & & $33.68^{\mathrm{b}}$ & $34.22^{\mathrm{b}}$ & $34.50^{\mathrm{b}}$ \\
\hline & & & & $82.00^{c}$ & $88.72^{\mathrm{a}}$ & $1.54^{a}$ & & & $0.452^{\mathrm{a}}$ & & & $36.87^{a}$ & $37.47^{\mathrm{a}}$ & $37.79^{\mathrm{a}}$ \\
\hline & & & & & $89.77^{a}$ & $1.58^{\mathrm{a}}$ & & & $0.426^{\mathrm{a}}$ & & $0.432^{\mathrm{ab}}$ & $37.82^{\mathrm{a}}$ & $38.45^{\mathrm{a}}$ & $38.77^{a}$ \\
\hline & & & & & & & & & & & & & & \\
\hline
\end{tabular}

*Initial reducing sugars available for fermentation $(\mathrm{g} / \mathrm{L})$ in saccharified liquor from fed-batch system (after $96 \mathrm{~h}$ saccharification);

** indicates the Hydrolysis Yield as per the equation 1 (includes the pretreatment yield also);

$* * * Y_{\mathrm{E}}$ : $\mathrm{g}$ ethanol produced/g sugar consumed, means with different superscripts in each column are significant at $\mathrm{p}<0.05$

Pretreatment related differences in RS release during saccharification were not evident within VB and PK peels, while significantly higher release was noticed from steam pretreated AG peel and MVW compared to DSA (see Table 1). It was also found that the HY \% giving RS release as percentage of the potentially available sugars from carbohydrate was the highest for MVW hydrolysates from both steam and DSA pretreatments. Previous studies showed that MVW had the lowest content of cellulose and hemicellulose (ca. $12 \%$ each) while $c a .28 \%$ starch was also present This coupled with the low lignin content (see Table 1) might have led to the higher hydrolysis of MVW during enzymatic saccharification.

Earlier studies on batch $v$ fed batch saccharification (15\% substrate loading) of steam or DSA pretreated vegetable residues showed that the latter was highly effective in enhancing the RS content in hydrolysates (Mithra et al., 2018). Furthermore the increase in RS after $96 \mathrm{~h}$ saccharification was not significant for most residues and hence in the present study on F-SHFthe hydrolysis time was curtailed to $96 \mathrm{~h}$. Very high HY values indicated that high conversion rate of carbohydrates to RS was possible because of the use of a complement of three enzymes such as cellulase, xylanase and starch hydrolysing enzyme, Stargen (see Table 2). Previous studies optimized the level of these enzymes and the same levels were used in the present study also wherein it was proved that Stargen levels could be halved for DSA pretreated biomass due to the high content of starch hydrolysis at the pretreatment stage itself (Mithra and Padmaja, 2017 b; Mithra et al., 2017). Zhou et al. (2008) also stressed the need for a well balanced enzyme cocktail to obtain high fermentable sugar yield from LCBs. Zhang and Richard (2011) utilized food waste containing 34.8\% starch as substrate for ethanol production and employed amylases for saccharification. Moon et al. (2009) used high starch $(30.1 \% \mathrm{w} / \mathrm{v})$ and fiber $(14.9 \% \mathrm{w} / \mathrm{v})$ containing waste and could get high RS yields when cellulases and amylases were used in the cocktail. Surfactants such as Tween 20 and PEG 4000 along with sodium borohydride might also have facilitated high HY \% by reducing the chances of inhibition of saccharifying enzymes by toxic inhibitors generated during pretreatment. Several reports indicated the efficacy of these chemicals in enhancing the RS content in the hydrolysates (Börjesson et al., 2007; Cavka and Jönsson, 2013; Eriksson et al., 2002).

A similar pattern of RS consumption was obtained during 24-72 $\mathrm{h}$ fermentation of the hydrolysates in F-SHF with high consumption for PK and VB peels in both the pretreatments (see Table 2). Nevertheless maximum consumption occurred during the first $24 \mathrm{~h}$ of yeast growth, after which there was only negligible increase in RS consumption in all the samples. This indicated the possibility of restricting the fermentation time to $24 \mathrm{~h}$ for economic reasons. This is further supported by the high VEP (g/L.h) during the first $24 \mathrm{~h}$ which then drastically reduced to one-half of the initial $(24 \mathrm{~h})$ value in $48 \mathrm{~h}$. VEP was also higher for the DSA pretreated hydrolysates for all the residues. Matsakas et al. (2014) obtained very high VEP values of 2.32 and $2.85 \mathrm{~g} / \mathrm{L} . \mathrm{h}$ respectively for $25 \%$ and $45 \%(\mathrm{w} / \mathrm{v})$ loading using household food waste saccharified with cellulases and $\beta$-glucosidase. The 

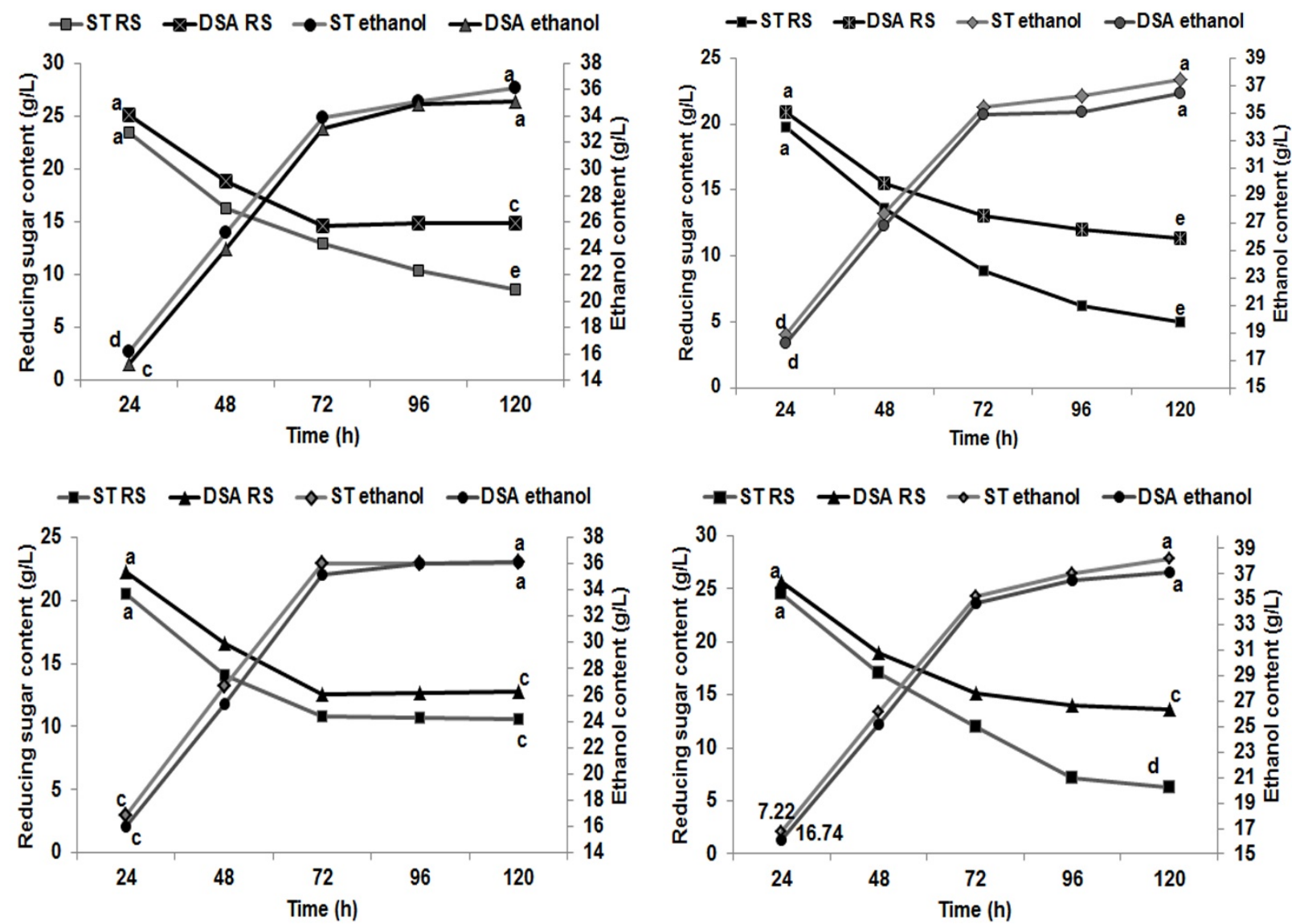

Figure 1. (a-d). Time course utilization of reducing sugars and production of ethanol during fed-batch SSF of pretreated LCSBs; (a)-AG peel, (b)- PK peel, (c)- VB peel, and (d)- MVW; Statistical comparison between values in each line and different alphabets for the initial and final values indicate significance at $\mathrm{p}<0.05$

ethanol yield $\mathrm{Y}_{\mathrm{E}}$ (g ethanol produced per gram RS consumed) and the ethanol content $(\mathrm{g} / \mathrm{L}$ ) of fermented broth showed that most ethanol production occurred within $24 \mathrm{~h}$ fermentation period. Among the two pretreatments, higher $\mathrm{Y}_{\mathrm{E}}$ and ethanol content were obtained for DSA pretreated residues and the very little increase obtained after $24 \mathrm{~h}$ fermentation again indicated that prolonging fermentation beyond $24 \mathrm{~h}$ was not economical (see Table 2).

Arapoglou et al. (2010) utilized a complement of three enzymes such as $\alpha$-amylase, cellulase and $\beta$-glucanase on potato peel waste for batch saccharification to obtain $18.5 \mathrm{~g} / \mathrm{L}$ RS which is not a high yield considering the total carbohydrate content of $68.7 \%$ including $52.14 \%$ starch and the ethanol yield reported was only $7.6 \mathrm{~g} / \mathrm{L}$. Similar low yields $(8 \mathrm{~g} / \mathrm{L})$ were reported from starch containing food wastes by Walker et al. (2012) by using amylase alone for saccharification, stressing the significance of enzyme cocktail to achieve higher RS yields. Nevertheless, higher ethanol yields have also been reported for starchy food wastes corroborating with our data (Matsakas et al., 2014; Moon et al., 2009). Bhatia and Paliwal (2010) reported ethanol yields of $30 \mathrm{~g} / \mathrm{L}$ from dilute acid hydrolysed waste banana peels using $S$. cerevisiae. A much higher RS content was obtained in the present study by adopting the fed batch approach and appropriate levels of enzymes in presence of detoxification chemicals.

The RS consumption in F-SSF for both the pretreatments was significantly higher than F-SHF (see Table 3). Nevertheless the VEP values were significantly lower than the F-SHF system, presumably due to the enhanced process duration of $120 \mathrm{~h}$ compared to only $72 \mathrm{~h}$ in F-SHF. The time course utilization of RS by yeast along with the ethanol production kinetics under F-SSF mode as presented in Fig.1 (a-d) indicated comparatively faster utilization of sugars during $24 \mathrm{~h}$ to $72 \mathrm{~h}$ period in both steam and DSA pretreatments. This also coincided with the ethanol productions, which were slowed down during 96-120 h. The final ethanol yield did not differ significantly neither between the residues nor pretreatments. However, RS consumption during fermentation by S. cerevisiae was significantly higher for PK peel and VB peel hydrolysates than the other two residues, even though this was not reflected in the VEP values or ethanol yields $\left(\mathrm{Y}_{\mathrm{E}}\right)$. No significant differences among the various residues were observed in the VEP values after $120 \mathrm{~h} \mathrm{F-SSF}$ (see Table 3); nevertheless higher $\mathrm{Y}_{\mathrm{E}}$ could be obtained for AG peel and MVW in both pretreatments indicating higher per se conversion of RS to ethanol in them (see Table 3 and Fig. 1 a-d). In the case of the other residues, part of the sugars might have been utilized for cell 
Table 3. Sugar consumption (g/L) and fermentation parameters after $120 \mathrm{~h}$ F-SSF of steam/DSA pretreated biomass

\begin{tabular}{lcccccc}
\hline \multirow{2}{*}{ Biomass } & \multicolumn{2}{c}{$\begin{array}{c}\text { Reducing sugar consumption } \\
(\mathbf{g} / \mathbf{L})\end{array}$} & \multicolumn{2}{c}{$\begin{array}{c}\text { Volumetric ethanol } \\
\text { productivity }(\mathbf{g} / \mathbf{L} . \mathbf{h})\end{array}$} & \multicolumn{2}{c}{$\begin{array}{c}\text { Ethanol yield } \\
\left(\mathbf{Y}_{\mathbf{E}}\right)\end{array}$} \\
\cline { 2 - 7 } & $\mathbf{S T}$ & DSA & ST & DSA & ST & DSA \\
\hline AG peel & $91.72^{\mathrm{d}}$ & $86.22^{\mathrm{c}}$ & $0.301^{\mathrm{b}}$ & $0.293^{\mathrm{c}}$ & $0.394^{\mathrm{a}}$ & $0.408^{\mathrm{b}}$ \\
\hline PK peel & $108.9^{\mathrm{b}}$ & $103.17^{\mathrm{b}}$ & $0.312^{\mathrm{a}}$ & $0.304^{\mathrm{b}}$ & $0.344^{\mathrm{b}}$ & $0.353^{\mathrm{c}}$ \\
\hline VB peel & $113.09^{\mathrm{a}}$ & $110.43^{\mathrm{a}}$ & $0.301^{\mathrm{b}}$ & $0.301^{\mathrm{b}}$ & $0.319^{\mathrm{c}}$ & $0.327^{\mathrm{d}}$ \\
\hline MVW & $94.53^{\mathrm{c}}$ & $87.16^{\mathrm{c}}$ & $0.318^{\mathrm{a}}$ & $0.310^{\mathrm{a}}$ & $0.404^{\mathrm{a}}$ & $0.426^{\mathrm{a}}$ \\
\hline
\end{tabular}

ST: steam pretreatment, DSA: dilute sulphuric acid pretreatment, $\mathrm{Y}_{\mathrm{E}}$ : $\mathrm{g}$ ethanol produced/g sugar consumed, means with different superscripts in each column are significant at $\mathrm{p}<0.05$

Table 4. Monosaccharide sugar profile $(\mathrm{g} / \mathrm{L})$ in hydrolysates $(96 \mathrm{~h})$ and fermented broth from vegetable wastes under F-SHF (72 h) and under F-SSF (120 h)

\begin{tabular}{|c|c|c|c|c|c|c|c|c|c|c|}
\hline \multirow{2}{*}{$\begin{array}{l}\text { Biomass } \\
\text { F-SHF }\end{array}$} & \multicolumn{2}{|c|}{ Mannose } & \multicolumn{2}{|c|}{ Galactose } & \multicolumn{2}{|c|}{ Glucose } & \multicolumn{2}{|c|}{ Arabinose } & \multicolumn{2}{|c|}{ Xylose } \\
\hline & & & & & & & & & & \\
\hline & $\mathrm{H}$ & FB & $\mathrm{H}$ & FB & $\mathrm{H}$ & FB & $\mathrm{H}$ & FB & $\mathrm{H}$ & FB \\
\hline \multicolumn{11}{|c|}{ Steam (ST)pretreatment } \\
\hline AG peel & 14.10 & 3.50 & 14.29 & 1.40 & 31.22 & 6.20 & - & - & 2.11 & 1.99 \\
\hline PK peel & - & - & 8.30 & 2.40 & 56.01 & 8.50 & - & - & 8.40 & 7.22 \\
\hline VB peel & 13.44 & 3.40 & - & - & 48.70 & 1.20 & - & - & 9.46 & 8.24 \\
\hline MVW & 2.30 & 1.40 & 1.26 & 0.55 & 44.17 & 2.00 & 3.40 & 2.70 & 9.46 & 8.45 \\
\hline \multicolumn{11}{|c|}{ DSA pretreatment } \\
\hline AG peel & 11.67 & 2.90 & 13.31 & 1.30 & 27.82 & 5.53 & - & - & 2.60 & 2.00 \\
\hline PK peel & - & - & 5.95 & 0.59 & 54.79 & 7.45 & - & - & 7.00 & 6.40 \\
\hline VB peel & 12.48 & 1.60 & - & - & 43.80 & 2.54 & - & - & 9.55 & 8.99 \\
\hline MVW & 1.07 & 0.46 & 0.77 & 0.78 & 40.06 & 1.50 & 2.30 & 1.90 & 7.60 & 7.00 \\
\hline
\end{tabular}

F-SSF (fermented broth, $120 \mathrm{~h}$ )

\begin{tabular}{|c|c|c|c|c|c|}
\hline & Mannose & Galactose & Glucose & Arabinose & Xylose \\
\hline \multicolumn{6}{|c|}{ Steam (ST)pretreatment } \\
\hline $\mathrm{AG}$ peel & 1.55 & 0.56 & 2.65 & - & 0.87 \\
\hline PK peel & - & 0.52 & 2.00 & - & 1.65 \\
\hline$\overline{\mathrm{VB} \text { peel }}$ & 1.50 & - & 0.56 & - & 4.33 \\
\hline MVW & 0.53 & 0.20 & 0.84 & 1.02 & 3.10 \\
\hline \multicolumn{6}{|c|}{ DSA pretreatment } \\
\hline AG peel & 3.14 & 1.30 & 5.11 & - & 2.09 \\
\hline PK peel & - & 0.45 & 5.08 & - & 4.44 \\
\hline VB peel & 1.11 & - & 2.36 & - & 7.95 \\
\hline MVW & 0.55 & 0.97 & 1.54 & 2.10 & 8.10 \\
\hline
\end{tabular}

Each value represents single data from pooled samples, H: hydrolysate (96 h) and FB: Fermented broth (72 h), F-SHF: fed-batch SHF, FSSF: fed-batch SSF

proliferation. An alternative possibility is the relative differences in the HPLC profile of monosaccharides and furan aldehydes.

\section{HPLC Profile of Monosaccharides}

The sugar profile of hydrolysates $(96 \mathrm{~h})$ from F-SHF as well as the fermented broth $(72 \mathrm{~h})$ and that from FSSF $(120 \mathrm{~h})$ as given in Table 4 showed that although glucose and xylose were uniformly present in all the samples, their values differed significantly with the highest content of glucose in the $96 \mathrm{~h}$ hydrolysates from steam and DSA pretreated PK peel in F-SHF system, while very low levels were observed from AG peel under similar conditions. Xylose content was also the lowest in the $96 \mathrm{~h}$ hydrolysates from AG peel. While mannose and galactose were also present in high levels in AG peel hydrolysates, mannose was absent in PK peel and galactose was absent in VB peel hydrolysates (see Table 4). Arabinose was present only in MVW hydrolysates and the differences in the monosaccharide profile indicated structural differences in the hemicellulose composition in the selected residues. Significant reduction in levels of hexose sugars was observed after fermentation in F-SHF (see Table 4), while xylose levels remained almost the same due to its non-utilization by S. cerevisiae (Olofsson et al., 2008).

The fermented broth from F-SSF of steam pretreated residues had significantly lower levels of hexoses and pentoses than the counterpart from F-SHF and a s the RS consumption was higher in the former mode than FSHF, the low levels of residual hexoses indicated better conversion to ethanol in F-SSF of steam pretreated biomass (see Table $2 v$ s Table 3). Nevertheless the low xylose levels might be due to the partial hydrolysis of hemicellulose after ST pretreatment coupled with its slow release from the remaining fraction compared to F-SHF. On the contrary, DSA pretreatment could effectively hydrolyse hemicellulose and hence the xylose levels in fermented broth were high in F-SSF as well (Table 4) and was the cumulative effect of pre-treatment and saccharification. 
Table 5. Total soluble phenolics (TSPs; $\mathrm{g} / \mathrm{L})$ in the hydrolysate $(96 \mathrm{~h}, \mathrm{~F}-\mathrm{SHF})$ and fermented broth after fermentation (72 h, F-SHF) and $120 \mathrm{~h}$ (F-SSF)) from steam/DSA pretreated biomass

\begin{tabular}{|c|c|c|c|c|c|c|}
\hline \multirow{2}{*}{ Biomass } & \multicolumn{2}{|c|}{$\begin{array}{c}96 \text { h hydrolysate } \\
\text { (F-SHF) }\end{array}$} & \multicolumn{2}{|c|}{$\begin{array}{l}\text { Fermented broth } \\
(72 \mathrm{~h}, \mathrm{~F}-\mathrm{SHF})\end{array}$} & \multicolumn{2}{|c|}{$\begin{array}{c}\text { Fermented broth } \\
(120 \mathrm{~h}, \mathrm{~F}-\mathrm{SSF})\end{array}$} \\
\hline & ST & DSA & ST & DSA & ST & DSA \\
\hline AG peel & $0.540^{\mathrm{d}}$ & $0.738^{\mathrm{b}}$ & $\begin{array}{l}0.406^{\mathrm{e}} \\
(24.81)\end{array}$ & $\begin{array}{l}0.576^{\mathrm{d}} \\
(21.95)\end{array}$ & $0.672^{c}$ & $0.884^{a}$ \\
\hline PK peel & $0.586^{\mathrm{d}}$ & $0.827 \mathrm{~b}$ & $\begin{array}{c}0.462 \\
(21.16) \\
\end{array}$ & $\begin{array}{l}0.655^{c} \\
(20.80) \\
\end{array}$ & $0.738^{b c}$ & $1.003^{a}$ \\
\hline VB peel & $0.439 c$ & $0.555^{\mathrm{b}}$ & $\begin{array}{r}0.284 \mathrm{e} \\
(35.31) \\
\end{array}$ & $\begin{array}{l}0.363^{\mathrm{d}} \\
(34.59) \\
\end{array}$ & $0.574^{b}$ & $0.601^{\mathrm{a}}$ \\
\hline MVW & $0.227^{b}$ & $0.180^{c}$ & $\begin{array}{l}0.213^{\mathrm{b}} \\
(6.17)\end{array}$ & $\begin{array}{l}0.168^{c} \\
(6.67)\end{array}$ & $0.336^{\mathrm{a}}$ & $0.352^{a}$ \\
\hline
\end{tabular}

* Figures in parentheses indicate the percentage decrease in TSPs during fermentation (72 h) by yeast, means with different superscripts in each row are significant at $\mathrm{p}<0.05$

Previous studies showed that as high as $42-48 \%$ of hemicellulose was hydrolysed at the DSA pretreatment stage (60 min) compared to only 18\% after steam pretreatment (45 min) (Mithra and Padmaja, 2016 a, 2017 a). Stenberg et al. (2000) observed that mannose (ca. $22 \mathrm{~g} / \mathrm{L}$ ) content in the liquor from steam pretreated $\mathrm{SO}_{2}$ impregnated spruce was more than glucose (ca. $16 \mathrm{~g} / \mathrm{L}$ ) even though native spruce had $40 \%$ glucan and $13 \%$ mannan which stressed the differential influence of pretreatments in hydrolysing/solubilising polysaccharides in the subsequent saccharification stage. The very high glucose levels in the hydrolysates from F-SHF resulted from the high content of starch as well in the LCSBs under study (see Table 1).

Rapid conversion of available glucose to ethanol by yeast in the first 6 to12 $\mathrm{h}$ after inoculation in SSF was reported by McIntosh et al. (2017) who found that $90 \%$ of ethanol production occurred during this period. As fed-batch substrate feeding strategy was adopted in the present study, continuous ethanol production was monitored up to $72 \mathrm{~h}$ although the rate of conversion of sugars to ethanol was reduced after $24 \mathrm{~h}$. Nguyen et al. (2018) obtained high yields of ethanol $(33.9 \mathrm{~g} / \mathrm{L})$ from soybean residue when galactose adapted yeast was used. Similar or higher yields of ethanol were obtained in the present study using traditional yeast adopting the fed-batch approach because of the high content of glucose in the hydrolysates compared to galactose.

\section{Inhibitor Changes in F-SHF vs FSSF}

The content of total soluble phenolics (TSPs) and furan aldehydes (furfural and 5-hydroxymethyl furfural) in the $96 \mathrm{~h}$ hydrolysates as well as the fermentation broth (from F-SHF and F-SSF) were quantified. The TSP content in the AG peel and PK peel were very high in the hydrolysates and fermented broth from DSA pretreatment (see Table 5). Lowest levels of TSPs were observed in the MVW samples. S. cerevisiae detoxified/assimilated part of the phenolics and higher extent of removal was noticed in samples with high levels. Approximately 6-7\% removal was only observed in MVW hydrolysates during fermentation, indicating that the phenol assimilation pathways were activated in yeast only when the levels exceeded a threshold limit. Previous studies showed that as high as 73 to $82 \%$ TSPs could be eliminated from steam and DSA pretreated slurry of the selected residues by Tween 20+PEG4000 supplemented systems, while sodium borohydride removed ca. 37-53\% TSPs (Mithra and Padmaja, 2016 b). Despite supplementation with the same level of detoxification chemicals the fermented broth from FSSF had high levels of TSPs (see Table 5). Although DSA pretreatment is reported as one of the most efficient ways to deconstruct LCBs, it leads to the accumulation of inhibitors such as phenolics, furfural and HMF (Ando et al., 1986). In the conventional LCB technology, interference from inhibitors is eliminated to a large extent through the removal of pretreated liquor fraction. Nevertheless this could not be applied to LCSBs having high content of starch and it necessitated whole slurry saccharification to avoid loss of fermentable sugars formed during pretreatment. The extent of removal of lignin released in situ during F-SSF through its binding with surfactants might be limited due to the competitive binding with enzymes which might be responsible for the high retention of TSPs in F-SSF samples despite 30 min contact time provided initially and prior to each substrate feeding to enable the substrates to interact with the surfactants.

Li et al. (2016) found that Tween 80 could enhance desorption of cellulases from both lignin and corn stover and attributed this to the possible competitive adsorption between cellulases and Tween 80 on them. The content of furan aldehydes in the $96 \mathrm{~h}$ hydrolysates and fermented broth (F-SHF and F-SSF) indicated that both the pretreatments resulted in the formation of only small quantities of the two furanoids (furfural and HMF) as compared to much higher values reported for many LCBs (Gupta et al., 2012; Li et al., 2016). Variation in levels was evident among the residues, with only negligible content of furfural in AG peel and lower levels of HMF in MVW than other residues (see Table 6). Xylose was the only pentose sugar present in the AG peel hydrolysates and that too in very low levels compared to the other residues and this might have resulted in the low conversion during pretreatment to furfural (see Table $4 v$ s Table 6). MVW having both arabinose and xylose as pentose sugars 
European Journal of Sustainable Development Research, 3(2), em0084

Table 6. HMF and furfural in the hydrolysate $(96 \mathrm{~h}, \mathrm{~F}-\mathrm{SHF}$ ) and fermented broth (after fermentation (72 h, F-SHF) and $120 \mathrm{~h}(\mathrm{~F}-\mathrm{SSF}))$ from steam/DSA pretreated biomass

\begin{tabular}{|c|c|c|c|c|c|c|}
\hline \multirow[t]{2}{*}{ Biomass } & \multicolumn{2}{|c|}{$\begin{array}{c}96 \text { h hydrolysate } \\
\text { (F-SHF) }\end{array}$} & \multicolumn{2}{|c|}{$\begin{array}{l}\text { Fermented broth } \\
(72 \mathrm{~h}, \mathrm{~F}-\mathrm{SHF})\end{array}$} & \multicolumn{2}{|c|}{$\begin{array}{l}\text { Fermented broth } \\
(120 \mathrm{~h}, \mathrm{~F}-\mathrm{SSF})\end{array}$} \\
\hline & ST & DSA & ST & DSA & ST & DSA \\
\hline \multicolumn{7}{|c|}{ HMF (mg/L) } \\
\hline AG peel & 56.61 & 85.45 & $\begin{array}{l}45.26 \\
(20.05)\end{array}$ & $\begin{array}{c}74.52 \\
(12.79) \\
\end{array}$ & 62.25 & 89.77 \\
\hline PK peel & 61.25 & 84.35 & $\begin{array}{c}50.13 \\
(18.16) \\
\end{array}$ & $\begin{array}{c}73.46 \\
(12.91) \\
\end{array}$ & 66.88 & 89.09 \\
\hline VB peel & 46.55 & 67.15 & $\begin{array}{c}34.68 \\
(25.50)\end{array}$ & $\begin{array}{c}55.28 \\
(17.68)\end{array}$ & 52.18 & 72.09 \\
\hline MVW & 32.35 & 29.65 & $\begin{array}{c}19.77 \\
(38.89)\end{array}$ & $\begin{array}{c}16.08 \\
(45.77)\end{array}$ & 37.99 & 34.19 \\
\hline \multicolumn{7}{|c|}{ Furfural (mg/L) } \\
\hline AG peel & 10.57 & 12.70 & $\begin{array}{l}10.04 \\
(5.01)\end{array}$ & $\begin{array}{c}10.09 \\
(20.55)\end{array}$ & 16.24 & 13.01 \\
\hline PK peel & 37.99 & 31.89 & $\begin{array}{c}32.85 \\
(13.53)\end{array}$ & $\begin{array}{l}29.27 \\
(8.22)\end{array}$ & 31.47 & 34.89 \\
\hline VB peel & 42.62 & 43.01 & $\begin{array}{c}37.30 \\
(12.48) \\
\end{array}$ & $\begin{array}{l}40.57 \\
(5.67) \\
\end{array}$ & 42.87 & 47.66 \\
\hline $\mathrm{MVW}$ & 57.44 & 44.53 & $\begin{array}{c}49.99 \\
(12.97)\end{array}$ & $\begin{array}{l}40.17 \\
(9.79)\end{array}$ & 44.98 & 47.55 \\
\hline
\end{tabular}

* Each value represents single data from pooled samples; figures in parentheses indicate the percentage decrease in HMF and furfural during fermentation $(72 \mathrm{~h}$ ) by yeast

had higher levels of furfural than others. On the contrary, HMF levels were low in MVW samples due to the lower content of hexoses (glucose+galactose+mannose) in them compared to the other residues. Greater degree of assimilation/detoxification of furfural and HMF by yeast was observed in samples having higher levels of these and the percentage decrease during fermentation ranged from 5-21\% (furfural) and 13-46\% (HMF). Palmqvist et al. (1999) observed that negative interaction effect existed between inhibitors and cumulative inhibition could affect the performance of yeast.

Phenolic inhibitors have greater inhibitor effect than corresponding levels of furfural, HMF or weak acids (Larsson et al., 1999). Ando et al. (1986) found that 4-hydroxybenzoic acid inhibited fermentation by $S$. cerevisiae at levels of $1.0 \mathrm{~g} / \mathrm{L}$, while vanillin present at similar levels caused only $25 \%$ decrease in ethanol yield. Approximately $21-35 \%$ decrease in TSPs were observed during fermentation in the present study (see Table 5) possibly due to assimilation by yeast and capacity of $S$. cerevisiae to assimilate vanillin, hydroxyl benzaldehyde and syringaldehyde has been demonstrated by Delgenes et al. (1996). Zha et al. (2012) compared the inhibitory effect of several compounds present in LCB hydrolystaes and found that only furfural and benzoic acid significantly affected yeast growth.

\section{Comparative Ethenol Recovery under F-SHF and F-SSF from Steam or DSA-Pretreated Biomass}

The fermentation efficiency (FE \%) was compared for the steam and DSA pretreated biomass under the two modes such as F-SHF and F-SSF and it was found that samples subjected to DSA pretreatment had significant high FE values under the F-SHF mode (85-97\%). Despite the high RS consumption under the F-SSF mode, ethanol yield was not proportionately increased in PK and VB peel samples and hence the FE values were low in both DSA and steam pretreated samples (see Table 2 vs Table 7). This was because part of the RS was consumed by yeast for its multiplication in certain residues such as PK and VB peels and hence was not getting fully converted to ethanol. Nevertheless this was not reflected in the ethanol productivity $(\mathrm{ml} / \mathrm{kg}$ biomass) as the ethanol content in the fermented broth from F-SSF for these residues was either equal to or slightly higher than AG peel broth.

Lowest ethanol productivity was observed for steam pretreated residues under F-SHF and while F-SHF of DSA pretreatment gave the highest ethanol recovery from VB and PK peels, the other two residues gave the highest ethanol recovery (294 and $310 \mathrm{ml} / \mathrm{kg}$ from AG peel and MVW respectively) under F-SSF of steam pretreatment (see Table 7). However when compared to the F-SSF of DSA pretreated biomass, the increase in ethanol recovery was only 7-8 ml/kg for F-SSF of steam pretreatment for residues other than VB peel, while similar ethanol recovery $(293 \mathrm{ml} / \mathrm{kg})$ was obtained for VB peel for steam or DSA pretreatment under F-SSF.

Higher ethanol yields have been reported in F-SSF by certain researchers, while others observed that F-SSF was superior to batch mode, only when the enzyme feeding strategy was altered (Hoyer et al., 2010; Modig et al., 2008). Rudolf et al. (2005) compared the SSF under batch or fed batch mode with only enzyme feeding and found that yeast was inhibited to a greater extent in the former mode. Although the major disadvantage of SSF is reported as the sub-optimal action of saccharifying enzyme at the compromising temperature $35-37^{\circ} \mathrm{C}$ and $\mathrm{pH} 4.5$, when traditional yeast is used, the need for only one reactor vessel and mitigation of enzyme inhibition by sugars due to 
Table 7. Comparative Fermentation Efficiency (\%) and ethanol productivity ( $\mathrm{ml} / \mathrm{kg}$ dry biomass) from steam and DSA pretreated vegetable processing residues under F-SHF and F-SSF

\begin{tabular}{|c|c|c|c|c|}
\hline \multirow{2}{*}{ Biomass } & \multicolumn{2}{|c|}{ Steam pretreated } & \multicolumn{2}{|c|}{ DSA pretreated } \\
\hline & F-SHF & F-SSF & F-SHF & F-SSF \\
\hline \multicolumn{5}{|c|}{ Fermentation Efficiency (\%) } \\
\hline AG peel & $78.06^{\mathrm{b}}$ & $77.10^{\mathrm{b}}$ & $96.99^{a}$ & $79.80^{\mathrm{b}}$ \\
\hline PK peel & $76.39^{\mathrm{b}}$ & $67.28^{\mathrm{d}}$ & $91.78^{a}$ & $69.08^{c}$ \\
\hline$\overline{\text { VB peel }}$ & $74.44^{b}$ & $62.50^{\mathrm{d}}$ & $84.52^{a}$ & $64.04^{c}$ \\
\hline$\overline{\mathrm{MVW}}$ & $74.82^{\mathrm{d}}$ & $79.00^{c}$ & $89.94^{a}$ & $83.38^{\mathrm{b}}$ \\
\hline \multicolumn{5}{|c|}{ Ethanol productivity (ml/kg dry biomass) } \\
\hline AG peel & $\begin{array}{l}229.86^{\mathrm{d}} \\
(218.51)\end{array}$ & $\begin{array}{l}293.82^{a} \\
(280.81)\end{array}$ & $\begin{array}{l}280.56^{c} \\
(269.34)\end{array}$ & $\begin{array}{l}285.88^{b} \\
(275.97)\end{array}$ \\
\hline PK peel & $\begin{array}{l}256.57^{d} \\
(245.80)\end{array}$ & $\begin{array}{c}304.39 \mathrm{~b} \\
(291.70)\end{array}$ & $\begin{array}{c}307.28^{a} \\
(297.72)\end{array}$ & $\begin{array}{l}296.07 \mathrm{c} \\
(284.77)\end{array}$ \\
\hline$\overline{\text { VB peel }}$ & $\begin{array}{l}264.54^{c} \\
(254.86)\end{array}$ & $\begin{array}{l}293.66^{\mathrm{b}} \\
(283.22)\end{array}$ & $\begin{array}{c}315.24^{a} \\
(308.91)\end{array}$ & $\begin{array}{l}293.80^{\mathrm{b}} \\
(283.40)\end{array}$ \\
\hline$\overline{\mathrm{MVW}}$ & $\begin{array}{l}238.72^{\mathrm{d}} \\
(226.37)\end{array}$ & $\begin{array}{l}310.24^{a} \\
(297.13)\end{array}$ & $\begin{array}{l}289.41^{\mathrm{c}} \\
(280.97)\end{array}$ & $\begin{array}{l}301.93^{\mathrm{b}} \\
(291.59)\end{array}$ \\
\hline
\end{tabular}

* Figures in parentheses indicate the recovery through distillation (pooled from three replicates), other values are mean from three replicates; means with different superscripts in each row are significant at $\mathrm{p}<0.05$

Table 8. Requirement of enzymes, other additives and processing conditions in F-SHF and F-SSF of steam and DSA pretreated biomass*

\begin{tabular}{|c|c|c|c|c|}
\hline \multirow{2}{*}{ Materials and conditions } & \multicolumn{2}{|c|}{ Steam pretreated } & \multicolumn{2}{|c|}{ DSA pretreated } \\
\hline & $\overline{\mathrm{F}-\mathrm{SHF}}$ & F-SSF & F-SHF & F-SSF \\
\hline \multicolumn{5}{|l|}{ Enzyme dosage } \\
\hline Ecozyme RT80 & $16 \mathrm{FPU} / \mathrm{g}$ cellulose & $24 \mathrm{FPU} / \mathrm{g}$ cellulose & 16 FPU/g cellulose & $24 \mathrm{FPU} / \mathrm{g}$ cellulose \\
\hline Ecozyme XY50 & $3.0 \mathrm{mg}$ protein $/ \mathrm{g} \mathrm{HC}$ & $4.5 \mathrm{mg}$ protein $/ \mathrm{g} \mathrm{HC}$ & $3.0 \mathrm{mg}$ protein $/ \mathrm{g} \mathrm{HC}$ & $4.5 \mathrm{mg}$ protein $/ \mathrm{g} \mathrm{HC}$ \\
\hline Stargen & $2.40 \mathrm{mg}$ protein/g biomass & $2.67 \mathrm{mg}$ protein/g biomass & $\begin{array}{l}1.20 \mathrm{mg} \\
\text { protein /g biomass }\end{array}$ & $1.33 \mathrm{mg}$ protein /g biomass \\
\hline \multicolumn{5}{|c|}{ Detoxification chemical mix (DCM) } \\
\hline Tween 20 & $2.5 \mathrm{ml} / \mathrm{L}$ slurry & $2.5 \mathrm{ml} / \mathrm{L}$ slurry & $2.5 \mathrm{ml} / \mathrm{L}$ slurry & $2.5 \mathrm{ml} / \mathrm{L}$ slurry \\
\hline PEG 4000 & $2.5 \mathrm{~g} / \mathrm{L}$ slurry & $2.5 \mathrm{~g} / \mathrm{L}$ slurry & $2.5 \mathrm{~g} / \mathrm{L}$ slurry & $2.5 \mathrm{~g} / \mathrm{L}$ slurry \\
\hline Sodium borohydride & $1.5 \mathrm{~g} / \mathrm{L}$ slurry & $1.5 \mathrm{~g} / \mathrm{L}$ slurry & $1.5 \mathrm{~g} / \mathrm{L}$ slurry & $1.5 \mathrm{~g} / \mathrm{L}$ slurry \\
\hline \multicolumn{5}{|l|}{ Other additives } \\
\hline Yeast feeding & $10 \mathrm{~g}$ dry yeast/L slurry & $14 \mathrm{~g}$ dry yeast/L slurry & $10 \mathrm{~g}$ dry yeast/L slurry & $14 \mathrm{~g}$ dry yeast/L slurry \\
\hline Nutrient solution & $1.67 \mathrm{ml} / \mathrm{L}$ slurry & $1.50 \mathrm{ml} / \mathrm{L}$ slurry & $1.67 \mathrm{ml} / \mathrm{L}$ slurry & $1.50 \mathrm{ml} / \mathrm{L}$ slurry \\
\hline \multicolumn{5}{|l|}{ Processing conditions } \\
\hline Pretreatment conditions & $\begin{array}{l}\text { Steam for } 45 \mathrm{~min} ; 100^{\circ} \mathrm{C} \text {; } \\
40 \% \mathrm{MC}\end{array}$ & $\begin{array}{l}\text { Steam for } 45 \mathrm{~min} ; 100^{\circ} \mathrm{C} \text {; } \\
40 \% \mathrm{MC}\end{array}$ & $\begin{array}{l}0.1 \mathrm{M} \mathrm{H}_{2} \mathrm{SO}_{4} ; 121{ }^{\circ} \mathrm{C} ; \\
0.102 \mathrm{MPa} \text { pressure; } 60 \\
\text { min. }\end{array}$ & $\begin{array}{l}0.1 \mathrm{M} \mathrm{H}_{2} \mathrm{SO}_{4} ; 121{ }^{\circ} \mathrm{C} ; \\
0.102 \mathrm{MPa} \text { pressure; } 60 \mathrm{~min} .\end{array}$ \\
\hline Temperature & $\begin{array}{l}50^{\circ} \mathrm{C} \text { for } 96 \mathrm{~h} \text { followed by } \\
37^{\circ} \mathrm{C} \text { for } 72 \mathrm{~h}\end{array}$ & $37^{\circ} \mathrm{C}$ for $120 \mathrm{~h}$ & $\begin{array}{l}50^{\circ} \mathrm{C} \text { for } 96 \mathrm{~h} \text { followed } \\
\text { by } 37^{\circ} \mathrm{C} \text { for } 72 \mathrm{~h}\end{array}$ & $37^{\circ} \mathrm{C}$ for $120 \mathrm{~h}$ \\
\hline $\mathrm{pH}$ & $\begin{array}{l}5.0 \text { for } 96 \mathrm{~h} \text { followed by } 4.5 \\
\text { for } 72 \mathrm{~h}\end{array}$ & 5.0 for $120 \mathrm{~h}$ & $\begin{array}{l}5.0 \text { for } 96 \mathrm{~h} \text { followed by } \\
4.5 \text { for } 72 \mathrm{~h}\end{array}$ & 5.0 for $120 \mathrm{~h}$ \\
\hline Total time & $\begin{array}{l}96 \mathrm{~h} \text { for saccharification and } \\
72 \mathrm{~h} \text { for fermentation (168 } \\
\text { h) }\end{array}$ & $\begin{array}{l}120 \mathrm{~h} \text { for saccharification } \\
\text { and fermentation }\end{array}$ & $\begin{array}{l}96 \mathrm{~h} \text { for saccharification } \\
\text { and } 72 \mathrm{~h} \text { for fermentatior } \\
(168 \mathrm{~h})\end{array}$ & $\begin{array}{l}120 \mathrm{~h} \text { for saccharification } \\
\text { and fermentation }\end{array}$ \\
\hline
\end{tabular}

* MC: moisture content; HC: hemicellulose

the simultaneous conversion to ethanol (Öhgren et al., 2007; Saha et al., 2013) make F-SSF cost-effective if the ethanol yields are reasonably good.

A comparison of the enzyme dosage, detoxification chemical mix levels as well as yeast feeding levels under the four processes adopted in the study as well as the processing conditions is provided in Table 8 . As the cost of pretreatment and enzymes have been reported as major factors contributing to the overall cost in $2 \mathrm{G}$ ethanol production (Sun and Cheng, 2002; Wyman, 1999), a major aim was to compare the yield of ethanol against the process operations. It could be seen from Table 8 that the F-SSF (both steam and DSA pretreatment) had significantly higher requirement of cellulase (Ecozyme RT80) and xylanase (Ecozyme XY50) than the corresponding F-SHF mode in which enzymes were fed only initially. Furthermore requirement of Stargen was only half the levels in both F-SHF and F-SSF from DSA pretreatment and the cumulative enzyme loading was thus the lowest in F-SHF of DSA pretreated biomass. This coupled with the possibility of reducing the fermentation time to $24 \mathrm{~h}$ in F-SHF (as there was no proportionate increase in ethanol production after $24 \mathrm{~h}$ up to $72 \mathrm{~h}$ ), thus equating the overall process time in both the modes to $120 \mathrm{~h}$ makes F-SHF of DSA pretreated biomass the most advantageous process for the selected biomass. 


\section{CONCLUSIONS}

The effect of fed batch substrate loading under SHF or SSF mode on ethanol production from vegetable processing residues was investigated using steam or DSA pretreated peels of ash gourd, pumpkin or vegetable banana as well as mixed vegetable waste. The volumetric ethanol productivity (g/L.h), ethanol yields (g ethanol produced/g sugar consumed) and ethanol contents $(\mathrm{g} / \mathrm{L})$ were higher from DSA pretreated biomass than steam pretreatment under F-SHF mode. However the ethanol yield and content did not differ significantly between the two pretreatments for the residues under F-SSF mode. Significantly higher RS utilization was observed towards the last phase $(72-120 \mathrm{~h})$ in steam pretreated biomass under F-SSF than DSA pretreated counterparts. Mannose and galactose were present in high levels in AG peel hydrolysates; however mannose was absent in PK peel and galactose was absent in VB peel hydrolysates. This suggested the possibility of structural variations in the hemicellulose composition in the residues. Very high consumption of hexoses during fermentation was observed in DSA pretreatment than steam pretreatment. The fermented broth from F-SSF retained higher levels of inhibitors such as phenolics, HMF and furfural compared to F-SHF although detoxification chemicals (Tween 20+PEG+sodium borohydride) were supplemented at equal levels to both the systems. A comparison of the ethanol productivity $(\mathrm{ml} / \mathrm{kg})$ under the various processes vis-à-vis enzyme and yeast feeding levels, pretreatment conditions, overall processing time etc. showed that F-SSF (both pretreatments) had higher requirement of enzymes and yeast than F-SHF. Furthermore the possibility to curtail fermentation at $24 \mathrm{~h}$ under F-SHF mode due to very low ethanol production after $24 \mathrm{~h}$ equated the processing time under the two modes to $120 \mathrm{~h}$ and hence F-SHF could be considered as the most advantageous process for the selected residues.

\section{ACKNOWLEDGEMENTS}

Thanks are due to the Director, ICAR- CTCRI for the facilities provided for the study, Dr. J. Sreekumar, Principal Scientist (Agricultural Statistics), ICAR-CTCRI for the help extended in statistical analyses and Dr. A. N. Jyothi, Principal Scientist as well as Mr. V. R. Vishnu, Senior Research Fellow, ICAR-CTCRI for the support extended for the HPLC analyses. This work was supported by the (Kerala State Council for Science, Technology \& Environment, Kerala, India) under Grant (number 853/2015/KSCSTE).

\section{ABBREVIATIONS}

$\begin{array}{ll}\text { F-SHF } & \text { Fed-batch separate hydrolysis and fermentation } \\ \text { F-SSF } & \text { Fed-batch simultaneous saccharification and fermentation } \\ \text { VEP } & \text { Volumetric ethanol productivity } \\ \text { ST } & \text { Steam pretreatment } \\ \text { DSA } & \text { Dilute sulphuric acid } \\ \text { HPLC } & \text { High performance liquid chromatography } \\ \text { GHG } & \text { Green house gas } \\ \text { LCB } & \text { Lignocellulosic biomass } \\ \text { 2G } & \text { Second generation } \\ \text { LCSB } & \text { Lignocellulo-starch biomass } \\ \text { AG } & \text { Ash gourd } \\ \text { PK } & \text { Pumpkin } \\ \text { VB } & \text { Vegetable banana } \\ \text { MVW } & \text { Mixed vegetable waste } \\ \text { GAU } & \text { Glucoamylase unit } \\ \text { HY } & \text { Hydrolysis yield } \\ \text { C } & \text { Cellulose } \\ \text { HC } & \text { Hemicellulose } \\ \text { S } & \text { Starch } \\ \text { PEG } & \text { Polyethylene glycol } \\ \text { FPU } & \text { Filter paper unit } \\ \text { YE } & \text { Ethanol yield } \\ \text { RS } & \text { Reducing sugar } \\ \text { TSP } & \text { Total soluble phenolics } \\ \text { HMF } & \text { Hydroxymethyl furfural } \\ \end{array}$




\section{CONFLICTS OF INTEREST}

The authors declare no conflict of interest.

\section{REFERENCES}

Alvira, P., Tomas-Pejo, E., Ballesteros, M. and Negro, M. J. (2010). Pretreatment technologies for an efficient bioethanol production process based on enzymatic hydrolysis: A review. Bioresour Technol, 101, 4851-4861. https://doi.org/10.1016/j.biortech.2009.11.093

Ando, S., Arai, I., Kiyoto, K. and Hanai, S. (1986). Identification of aromatic monomers in steam-exploded poplar and their influences on ethanol fermentation by Saccharomyces cerevisiae. J. Fermen Technol, 64, 567-570. https://doi.org/10.1016/0385-6380(86)90084-1

Anon. (2009). STARGENTM002: Granular starch hydrolyzing enzyme for ethanol production. Product information. Published by Genencor International, a Division of Danisco, Danisco US Inc. Available at: http://www.genencor.com (Accessed 22 December 2014)

Anon. (1962). The Wealth of India. Raw Materials, Vol. 6, CSIR, New Delhi, India.

Arapoglou, D., Varzakas, T., Vlyssides, A. and Israilides, C. (2010). Ethanol production from potato peel waste (PPW). Waste Manag, 30, 1898-1902. https://doi.org/10.1016/j.wasman.2010.04.017

Barcelos, C. A., Maeda, R. N., Betancur, G. J. V. and Pereira, N. (2011). Ethanol production from sorghum grains (Sorghum bicolor (L.)Moench): Evaluation of the enzymatic hydrolysis and the hydrolysatefermentability. Braz J Chem Eng, 28, 597-604. Available at: http://www.abeq.org.br/bjche https://doi.org/10.1590/S010466322011000400005

Bhatia, L. and Paliwal, S. (2010). Banana peel waste as substrate for ethanol production. Inter J Biotechnol Bioeng Res, 1, 213-218.

Börjesson, J., Peterson, R. and Tjerneld, F. (2007). Enhanced enzymatic conversion of softwood lignocelluloses by poly (ethylene glycol) addition. Ensyme Microb Technol, 40(4), 754-762. https://doi.org/10.1016/j.enzmictec.2006.06.006

Bussamra, B. C., Freitas, S. and Costa, A. C. (2015). Improvement on sugarcane bagasse hydrolysis using enzymatic mixture designed cocktail. Bioresour Technol, 187, 173-18. https://doi.org/10.1016/j.biortech.2015.03.117

Caputi, Jr. A., Ueda, M. and Brown, T. (1968). Spectrophotometric determination of ethanol in wine. Am J Enol Viticult, 19, 160-165.

Cavka, A. and Jönsson, L. J. (2013). Detoxification of lignocellulosichydrolysates using sodium borohydride. Bioresour Technol, 136, 368-376. https://doi.org/10.1016/j.biortech.2013.03.014

Delgenes, J.P., Moletta, R. and Navarro, J. M. (1996). Effects of lignocelluloses degradation products on ethanol fermentation of glucose and xylose by Saccharomyces cerevisiae, Pichiastipitis and Candida shehatae. Ensyme Microb Technol, 19, 220-225. https://doi.org/10.1016/0141-0229(95)00237-5

Divya Nair, M. P., Padmaja, G. and Moorthy, S. N. (2011). Biodegradation of cassava starch factory residue using a combination of cellulases, xylanases and hemicellulases. Biomass Bioener, 35, 1211-1218. https://doi.org/10.1016/j.biombioe.2010.12.009

Eriksson, T., Börjesson, J. and Tjerneld, F. (2002). Mechanism of surfactant effect in enzymatic hydrolysis of lignocellulose. Ensyme Microb Technol, 31(3), 353-364. https://doi.org/10.1016/S0141-0229(02)00134-5

FAOSTAT. (2016). Available at: www.fao.org/faostat/en/\#data (Accessed 27 March 2018)

Farrel, A. E., Pelvin, R. J., Turner, B. T., Jones, A. D., O’ Hare, M. and Kammen, D. M. (2006). Ethanol can contribute to energy and environmental goals. Science, 311, 506-508. https://doi.org/10.1126/science.1121416.

Ghose, T. K. (1987). Measurement of cellulase activities. Pure Appl Chem, 59, 257-268. http://dx.doi.org/10.1351/pac198759020257

Gupta, R., Kumar, S., Gomes, J. and Kuhad, R.C. (2012). Kinetic study of batch and fed-batch enzymatic saccharifiaction of pretreated substrate and subsequent fermentation to ethanol. Biotehnol Biofuels, 5, 16. https:// doi.org/10.1186/1754-6834-5-16

Hedge, J. E. and Hofreiter, B. T. (1962). Carbohydrate Chemistry, 17, (Whistler, R.L., \& Be Miller, J. N., eds) Academic Press, New York.

Himmel, M. E., Ding, S. Y., Johnson, D. K., Adney, W. S., Nimlo, M. R., Brady, J. W. and Foust, T. D. (2007). Biomass recalcitrance: Engineering plants and enzymes for biofuel production. Science, 315, 804-807. https://doi.org/10.1126/science.1137016

Hodge, D., Karim, M. N., Schell, D. J. and McMillan, J. D. (2008). Soluble and insoluble solids contributions to high-solids enzymatic hydrolysis of lignocellulose. Bioresour Technol, 99, 8940-8948. https://doi.org/10.1016/j.biortech.2008.05.015 
Hoyer, K., Galbe, M. and Zacchi, G. (2010). Effects of enzyme feeding strategy on ethanol yield in fed-batch simultaneous saccharification and fermentation of spruce at high dry matter. Biotechnol Biofuels, 3, 14. https://doi.org/10.1186/1754-6834-3-14

Larsson, S., Palmqvist, E., Hahn-Hägerdal, B., Tengborg, C, Stenberg, K., Zacchi, G. and Nilvebrant, N. O., (1999). The generation of fermentation inhibitors during dilute acid hydrolysis of softwood. Ensyme Microb Tecbnol, 24 (3-4), 151-159. https://doi.org/10.1016/S0141-0229(98)00101-X

Li, A., Antizar-Ladislao, B. and Khraisheh, M. (2007). Bioconversion of municipal solid waste to glucose for bioethanol production. Bioprocess Biosyst Eng, 30, 189-196. https://doi.org/10.1007/s00449-007-0114-3

Li, Y., Sun, Z. and Ge, X. (2016). Effects of lignin and surfactant on adsorption and hydrolysis of cellulases on cellulose. Biotechnol Biofuels, 9, 20. https://doi.org/10.1186/s13068-016-0434-0

Lin, C. S. K., Pfaltzgraff, L. A., Herrero-Davila, L., Mubofu, E. B., Abderrahim, S. and Clark, J. H., et al. (2013). Food waste as a valuable resource for the production of chemicals, materials and fuels. Current situation and global perspective. Energ Environ Sci, 6, 426-464. https://doi.org/10.1039/C2EE23440H

Lissens, G., Klinke, H., Verstraete, W., Ahring, B. and Thomsen, A. B. (2004). Wet oxidation treatment of organic household waste enriched with wheat straw for simultaneous saccharification and fermentation into ethanol. Environ Technol, 25, 647-655. https://doi.org/10.1080/09593330.2004.9619354

Luque, R. and Clark, J. (2013). Valorisation of food residues: waste to wealth using green chemical technologies. Sustain Chem Process, 1, 10. https://doi.org/10.1186/2043-7129-1-10

Matsakas, L., Kekos, D., Loizidou, M. and Christakopoulos, P. (2014). Utilization of household food waste for the production of ethanol at high dry material content. Biotechnology Biofuels, 7, 4. https://doi.org/10.1186/17546834-7-4

McIntosh, S., Palmer, J., Zhang, Z., Doherty, W. O. S., Yazdani, S. S., Sukumaran R. K. and Vacov, T. (2017). Simultaneous saccharification and fermentation of pretreatedEucalyptus grandis under high solids loading. Indus Biotechnol, 13(3), 131-140. https://doi.org/10.1089/ind.2016.0018

Mithra, M. G. and Padmaja, G. (2017a). Comparative alterations in the compositional profile of selected root and vegetable peels subjected to three pretreatments for enhanced saccharification. Internat J Environ Agric Biotechnol, 2(4), 1732-1744. https:// doi.org/10.22161/ijeab/2.4.34

Mithra, M. G. and Padmaja, G. (2016a). Compositional profile and ultrastructure of steam and dilute sulfuric acid pretreated root and vegetable processing residues. Current Biotechnol, 7. https://doi.org/10.2174/2211550105666160916124120

Mithra, M. G. and Padmaja, G. (2016b). Phenolic inhibitors of saccharification and fermentation in lignocellulostarch prehydrolysates and comparative efficacy of detoxification treatments. J Biomass Biofuel, 3. https://doi.org/10.11159/jbb.2016.001

Mithra, M. G. and Padmaja, G. (2017b). Strategies for enzyme saving during saccharification of pretreatedlignocellulo-starch biomass: Effect of enzyme dosage and detoxification chemicals. Heliyon, 3. https://doi.org/10.1016/j.heliyon.2017. e00384

Mithra, M. G., Sajeev, M. S. and Padmaja, G. (2018). Fed-batch saccharification as a strategy towards reducing enzyme dosage and enhancing fermentable sugar yield from pretreated lignocellulo-starch biomass. Waste Biomass Valor. https://doi.org/10.1007/s12649-018-0373-z

Mithra, M. G., Sreekumar, J. and Padmaja, G. (2017). Binary- and triple-enzyme cocktails and their application mode affect fermentable sugar release from pretreatedlignocellulo-starch biomass. Biomass Conver Biorefin, 8, 97111. https://doi.org/10.1007/s13399-017-0237-y

Modig, T., Almeida, J. R., Gorwa-Grauslund, M. F. and Lidén, G. (2008). Variability of the response of Saccharomyces cerevisiae strains to lignocellulose hydrolysate. Biotechnol Bioeng, 100, 423-429. https:// doi.org/10.1002/bit.21789

Moon, H. C., Song, I. S., Kim, J. C., Shirai, Y., Lee, D. H. and Kim, J. K., et al. (2009). Enzymatic hydrolysis of food waste and ethanol fermentation. Int J Energ Res., 33, 164-172. https:// doi.org/10.1002/er.1432

Nelson, N. (1944). A photometric adaptation of the Somogyi method for determination of glucose. J Biol Chem, 153, 375-380.

Nguyen, T. H., Ra, C. H, Sunwoo, I. Y., Sukwong, P., Jeong, G. T. and Kim, S. K. (2018). Bioethanol production from soybean residue via separate hydrolysis and fermentation. Appl Biochem Biotechnol, 184, 513-523. https://doi.org/10.1007/s12010-017-2565-6

Öhgren, K., Bura, R., Lesnicki, G., Saddler, J. and Zacchi, G. A. (2007). comparison between simultaneous saccharification and fermentation and separate hydrolysis and fermentation using steam pretreated corn stover. Process Biochem, 42, 834-839. https://doi.org/10.1016/j.procbio

Olofsson, K., Rudolf, A. and Lidén, G. (2008). Designing simultaneous saccharification and fermentation for improved xylose conversion by a recombinant strain of Saccharomyces cerevisiae. J Biotechnol, 134, 112-120. https://doi.org/10.1016/j.jbiotec.2008.01.004 
Palmqvist, E., Grage, H., Meinander, N. Q. and Hahn-Hägerdal, B. (1999). Main and interaction effects of acetic acid, furfural, and p-hydroxybenzoic acid on growth and ethanol productivity of yeasts. Biotechnol Bioeng, https:// doi.org/10.1002/(SICI) 1097-0290(19990405)63:13.3.CO,2-A

Pereira, S, C., Maehara, L., Machado, C. M. M. and Farinas, C. S. (2015). 2G ethanol from the whole sugarcane lignocellulosic biomass. Biotechnol Biofuels. https://doi.org/10.1186/s13068-015-0224-0

Pooja, N. S., Sajeev, M. S., Jeeva, M. L. and Padmaja, G. (2018). Bioethanol production from microwave-assisted acid or alkali-pretreated agricultural residues of cassava using separate hydrolysis and fermentation (SHF). Biotech, 8, 69. https://doi.org/10.1007/s13205-018-1095-4

Qin, W. (2010). High consistency ensymatic bydrolysis of lignocelluloses. MSc thesis, University of British Columbia, Vancouver, Canada, pp. 140.

Rudolf, A., Alkasrawi, M., Zacchi, G. and Lidén, G.A. (2005). Comparison between batch and fed-batch simultaneous saccharification and fermentation of steam pretreated spruce. Ensyme Microb Technol., 37, 195204. https://doi.org/10.1016/j.enzmictec.2005.02.013

Saha, B. C., Nichols, N. N. and Cotta, M. A. (2013). Comparison of separate hydrolysis and fermentation versus simultaneous hydrolysis and fermentation of pretreated wheat straw to ethanol by Saccharomyces cerevisiae. $J$ Biobased Materials Bioener, 7, 409-414. https://doi.org/10.1166/jbmb.2013.1366

Sarkar, N., Ghosh, S. K., Bannerjee, S. and Aikat, K. (2012). Bioethanol production from agricultural wastes. An overview. Renew Energ., 37, 19-27. https://doi.org/10.1016/j.renene.2011.06.045

SAS. (2010). Cary NC, USA, SAS Institute Inc.

Singh, A., Kuila, A., Adak, S., Bishai, M. and Banerjee, R. (2012). Utilization of vegetable wastes for bioenergy generation. Agri Res, 1, 213-222. https:// doi.org/10.1007/s40003-012-0030-x

Singleton, V. L. and Rossi, A. (1965). Colorimetry of total phenolics with phosphomolybdic-phosphotungstic acid reagents. Am J Enol Viticult, 16, 144-158.

Sreenivas, K. M., Chaudhari, K. and Lele, S. S. (2011). Ash gourd peel wax: Extraction, characterization and application as an edible coat for fruits. Food Sci Biotechnol, 20, 383-387. https://doi.org/10.1007/s10068-0110054-1

Stenberg, K., Bollók, M., Réczey, K., Galbe, M and Zacchi, G. (2000). Effect of substrate and cellulase concentration on simultaneous saccharification and fermentation of steam-pretreated softwood for ethanol production. Bio technol Bio eng, 68(2), 204-210. https://doi.org/10.1002/(SICI)10970290(20000420)68:2<204::AID-BIT9>3.0.CO,2-4

Sun, Y. and Cheng, J. (2002). Hydrolysis of lignocellulosic materials for ethanol production: a review. Bioresour Technol, 83, 1-11. https://doi.org/10.1016/S0960-8524(01)00212-7

Taherzadeh, M. J. and Karimi, K. (2008). Pretreatment of lignocellulosic wastes to improve ethanol and biogas production: a review. Int J Mol Sci, 9, 1621- 165. https://doi.org/10.3390/ijms9091621

Tang, Y. Q., Koike, Y., Liu, K. and An, M. Z., Morimura, S., Wu, X. L., Kida, K. (2008). Ethanol production from kitchen waste using the flocculating yeast, Saccharomyces cerevisiae strain KF-7. Biomass Bioener, 32, 1037-1045. https://doi.org/10.1016/j.biombioe.2008.01.027

Thomsen, S. T., Kádár, Z. and Schmidt, J. E. (2014). Compositional analysis and projected biofuel potentials from common West African agricultural residues. Biomass Bioener, 63, 210-217. https://doi.org/10.1016/j.biombioe.2014.01.045

Tomaz, T. and Roche, A. (2002). Hydrophobic interaction, chromatography of Trichoderma reesei cellulase on polypropylene glycol-sepharose. Separation Sci Technol, 37, 1-11. https://doi.org/10.1081/SS-120002741

Walker, K., Vadlani, P., Madl, R., Ugorowski, P. and Hohn, K. L. (2012). Ethanol fermentation from food processing waste. Environ Prog Sustain Energ, 32, 1280-1283. https://doi.org/10.1002/ep.11700

Wyman, C. E. (1999). Biomass ethanol: Technical progress, opportunities and commercial challenges. Annu Rev Energy Env, 24, 189-226. https://doi.org/10.1146/annurev.energy.24.1.189.

Yadav, S, K., Naseeruddin, S., Prashanthi, G. S., Sateesh, S and Rao, L. V. (2011). Bioethanol fermentation of concentrated rice straw hydrolyzate using co-culture of Saccharomyces cerevisiae and Pichia stipitis. Bioresour Technol., 102(11), 6473-6478. https://doi.org/10.1016/j.biortech.2011.03.019.

Yang, B. and Wyman, C.E. (2008). Pretreatment: The key to unlocking low cost cellulosic ethanol. Biofuels BioprodBioref, 2, 26-40. https://doi.org/10.1002/bbb.49.

Zacchi, G. and Axelsson, A. (1989). Economic evaluation of preconcentration in production of ethanol from dilute sugar solutions. Biotechnol Bioeng, 34(2), 223-33. https://doi.org/10.1002/bit.260340211

Zha, Y., Muilwijk, B., Coulier, L. and Punt, P. J. (2012). Inhibitory compounds in lignocellulosic biomass hydrolysates during hydrolysate fermentation processes. J. Bioproces Biotech. https://doi.org/10.4172/21559821.1000112

Zhang, B. and Shahbazi, A. (2011). Recent developments in pretreatment technologies for production of lignocellulosic biofuels. J. Petrol Environ Biotechnol, 2, 108-115. https://doi.org/10.4172/2157-7463.1000108 
Zhang, Y., Zhao, W., Li, B. and Li, H. (2018). Understanding the sustainability of fuel from the viewpoint of exergy. EurJ Sus Develop, 2, 09. https://doi.org/10.20897/ejosdr/76935

Zhang, C., Zhuang, X., Wang, Z.J., Matt, F., St. John, F. and Zhu, J. Y. (2013). Xylanase supplementation on enzymatic saccharification of dilute acid pretreated poplars at different severities. Cellulose, 20, 1937-1946. https://doi.org/10.10071s10570-013-9934-2

Zhang, X., Qin, W., Paice, M.G. and Saddler, J. N. (2009). High consistency enzymatic hydrolysis of hardwood substrates. Bioresour Technol, 100, 5890-5897. https://doi.org/10.1016/j.biortech.2009.06.082

Zhang, X. and Richard, T. (2011). Dual enzymatic saccharification of food waste for ethanol fermentation. In Proceedings of International Conference on Electrical and Control Engineering, 16-18, September, Yichang, ISBN 978-1-42448162-0. https://doi.org/10.1109/ICECENG.2011.6058308

Zhou, J., Wang, Y. H., Chu, J. Luo, L. Z., Zhuang, Y. P. and Zhang, S. L. (2008). Optimization of cellulase mixture for efficient hydrolysis of steam-exploded corn stover by statistically designed experiments. Bioresour Technol, 100, 819-825. https:// doi.org/10.1016/j.biortech.2008.06.068.

Zhou, T., Kong, Q., Huang, J., Dai, R. and Li, Q. (2007). Characterization of nutritional components and utilization of pumpkin. Food.Global Science Books, 313-321. 